UNIVERSIDADE DE SÃO PAULO

INSTITUTO DE MATEMÁTICA E ESTATÍSTICA

RODRIGO RUIZ CAMPOS

Argumentação e Demonstração dos Alunos do Ensino Médio: uma proposta de investigação matemática sobre crescimento e decrescimento de funções afins 
RODRIGO RUIZ CAMPOS

\title{
Argumentação e Demonstração dos Alunos do Ensino Médio: uma proposta de investigação matemática sobre crescimento e decrescimento de funções afins
}

\section{Versão Corrigida}

\author{
Esta versão da dissertação contém as correções e alterações sugeridas pela \\ comissão julgadora durante a defesa da versão original do trabalho, \\ realizada em 21/11/2017, no Instituto de Matemática e Estatística da \\ Universidade de São Paulo. \\ Área de Concentração: Ensino de Matemática \\ Orientador: Prof. Dr. Antônio Carlos Brolezzi
}


Nome: CAMPOS, Rodrigo Ruiz

Título: Argumentação e Demonstração dos Alunos do Ensino Médio: uma proposta de investigação matemática sobre crescimento e decrescimento de funções afins.

Esta versão da dissertação contém as correções e alterações sugeridas pela comissão julgadora durante a defesa da versão original do trabalho, realizada em 21/11/2017, no Instituto de Matemática e Estatística da Universidade de São Paulo.

Aprovado em: 21/11/2017

Banca Examinadora

Prof. Dr. Antônio Carlos Brolezzi (presidente)

Instituição: IME - USP

Prof. Dra ${ }^{a}$ Cristina Dalva van Berghem Motta

Instituição: FEDUC

Prof. Dra . Circe Mary Silva da Silva Dynnikov

Instituição: UFES

Resultado da defesa: Aprovado 


\section{Dedicatória}

Entre todas as descobertas que a matemática trouxe para a minha vida, as mais valiosas foram a amizade, o companheirismo e o amor. Este trabalho é dedicado à Angela, por todo seu carinho e compreensão ao longo destes anos. 


\section{Agradecimentos}

À minha mãe, Cida, que sempre acreditou em mim e esteve ao meu lado em todos os momentos da minha vida.

Aos meus irmãos Alexandre e Adriana, que me deram suporte ao longo do tempo para que eu pudesse me dedicar aos estudos.

Ao professor Dr. Antônio Carlos Brolezzi por todo aprendizado, crescimento e amadurecimento que me proporcionou durante a orientação.

Às professoras Dra . Circe Mary Silva da Silva Dynnikov e Dra ${ }^{a}$.Cristina Dalva van Berghem Motta pelas sugestões valiosas e pela participação da banca de defesa.

A todos os professores do Mestrado Profissional em Ensino de Matemática do IME-USP que contribuíram para a minha formação.

Em especial, às professoras lole de Freitas Druck, Martha Salerno Monteiro e Cláudia Cueva Candido pela honra de ter vocês como minhas professoras ao longo da minha trajetória como aluno do IME-USP. 
“[...] ensinar não é transferir conhecimento, mas criar as possibilidades para a sua própria produção ou a sua construção." (FREIRE, 1996, p.27). 


\section{Resumo}

CAMPOS, Rodrigo Ruiz. Argumentação e Demonstração dos Alunos do Ensino Médio: uma proposta de investigação matemática sobre crescimento e decrescimento de funções afins. 2017. 95 f. Dissertação (Mestrado Profissional em Ensino de Matemática - Instituto de Matemática e Estatística, Universidade de São Paulo, São Paulo, 2017.

O presente trabalho tem como objetivo estudar se atividades de investigação matemática podem ajudar a desenvolver a capacidade de argumentação e demonstração matemática nos alunos do Ensino Médio, abordando o tema do crescimento e decrescimento de funções afins. Para isso, propõe uma reflexão sobre o papel da argumentação e da demonstração na formação integral do aluno do ensino médio. Enfoca, em particular, a transição entre o ensino básico e o superior, estudando algumas de suas dificuldades. O trabalho explora a diferença entre esses níveis de ensino, considerando que, enquanto a escola básica trata a matemática baseada em procedimentos aritméticos e algébricos, do ponto de vista prático tais como contas, medições, equações, análise de dados -, o ensino superior exige mais abstração por parte do aluno onde a argumentação, o raciocínio lógico (dedutivo e indutivo) e as demonstrações são condições necessárias para a produção do conhecimento. Ao final, faremos uma proposta de atividade matemática através de uma abordagem investigativa, refletindo sobre como a demonstração, abordada dessa forma, pode contribuir para a formação integral do aluno e criar aproximações entre a forma como a matemática é tratada na escola básica e no ensino superior.

Palavras-chave: Argumentação. Demonstração. Investigação Matemática. Transição Escola Básica - Superior. Função Afim. 


\section{Abstract}

CAMPOS, Rodrigo Ruiz. Argumentation and Demonstration of High School Students: a proposal of mathematical investigation on growth and decrease of linear functions. 2017. 95 f. Dissertação (Mestrado Profissional em Ensino de Matemática - Instituto de Matemática e Estatística, Universidade de São Paulo, São Paulo, 2017.

This present work aims to study if mathematical research activities can help to develop mathematical argumentation and demonstration capacity in high school students, addressing the theme of growth and decrease of linear functions. For this, it proposes a reflection about the role of argumentation and demonstration in the integral formation of the high school student. It focuses on the transition between basic and higher education, studying some of its difficulties. The study explores the difference between these levels of education, whereas, while the basic school treats mathematics based on arithmetic and algebraic procedures from a practical point of view - such as arithmetic, measurements, equations, data analysis -, higher education demands from the student a greater abstraction level, where argumentation, logical reasoning (deductive and inductive) and demonstrations are necessary conditions to knowledge construction. In the end, we will propose a mathematical activity through an investigative approach, reflecting on how the demonstration, addressed in this way, can contribute to the integral formation of the student and create approximations between the way mathematics is treated in elementary school and in higher education.

Keywords: Argumentation. Demonstration. Mathematics investigation. Secondary-Tertiary Transition. Linear Functions. 


\section{Lista de Figuras}

Figura 1 - Diferenças entre a Matemática da Educação Básica e do Ensino Superior.

Figura 2 - Representação das relações entre ensino e investigação.

Figura 3 - Os diversos tipos de tarefas, em termos de dificuldade e estrutura.

Figura 4 - Eixo correspondente dos diferentes tipos de tarefas, quanto ao tempo. .38

Figura 5 - Eixo correspondente dos diferentes tipos de tarefas, quanto ao contexto. .38

Figura 6 - Representação gráfica da circunferência trigonométrica. .50

Figura 7 - Representação gráfica da imagem P nos demais quadrantes. .51

Figura 8 - Atividade de Investigação - Apresentação e Objetivos. .69

Figura 9 - Atividade de Investigação - Questão Motivadora. .70

Figura 10 - Atividade de Investigação - item 1 - comportamento empirista ingênuo. .71

Figura 11 - Atividade de Investigação - item 2 - experimento crucial. .72

Figura 12 - Atividade de Investigação - item 3 - generalização do exemplo .72

Figura 13 - Atividade de Investigação - item 4 - generalização do exemplo

Figura 14 - Atividade de Investigação - item 5 - generalização do exemplo.

Figura 15 - Atividade de Investigação - item 6 - experimento mental.

Figura 16 - Análise da atividade de investigação - Conjecturando .75

Figura 17 - Análise da atividade de investigação - Conjecturando com auxílio do professor .76

Figura 18 - Análise da atividade de investigação - Função afim crescente - Tabela do item 1. .77

Figura 19 - Análise da atividade de investigação - Função afim crescente - Argumentação do item 2.78

Figura 20 - Análise da atividade de investigação - Função afim crescente - itens 4 e 5 .79

Figura 21 - Análise da atividade de investigação - Função afim crescente - argumentação do item 4.79 Figura 22 - Análise da atividade de investigação - Função afim crescente - item 6 .80

Figura 23 - Análise da atividade de investigação - Função afim decrescente .81 


\section{Lista de Tabelas}

Tabela 1 - Principais diferenças entre Argumentação e Demonstração ............................................60

Tabela 2 - Principais características entre Ensino direto e Ensino-aprendizagem exploratória.............39

Tabela 3 - Atividade de Investigação - exemplo de resolução para o item 1 .....................................71

Tabela 4 - Atividade de Investigação - exemplo de resolução para o item 3 ......................................73 


\section{Sumário}

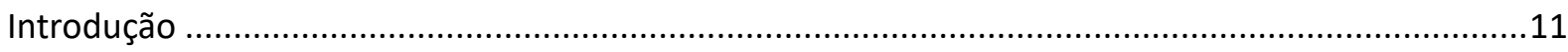

A Matemática entre o Ensino Médio e o Ensino Superior ................................................................15

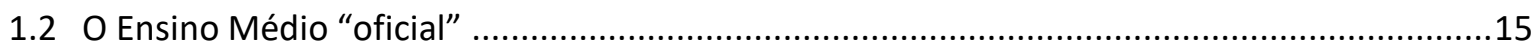

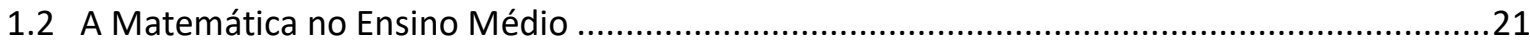

1.3 A matemática na transição para o Ensino Superior ................................................................25

A investigação matemática em sala de aula. ...................................................................................32

2.1 Investigação matemática segundo Ponte ……........................................................................

2.2 Uma metodologia de investigação matemática .................................................................... 34

2.3 Diferenças entre ensino direto e investigação matemática ....................................................36

A demonstração matemática no Ensino Médio ...................................................................................

3.1 O pensamento demonstrativo e a história da matemática .....................................................41

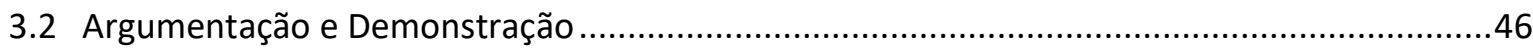

Uma proposta de investigação sobre a demonstração matemática. .................................................65

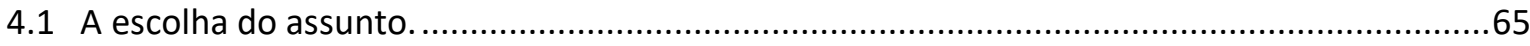

4.2 Estrutura de desenvolvimento da atividade de investigação ................................................68

4.2.1 Apresentação da atividade e sua interpretação pelos alunos. ……………….................68

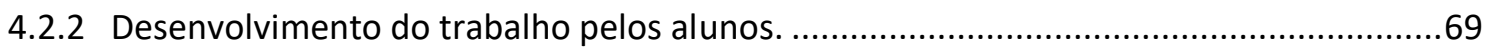

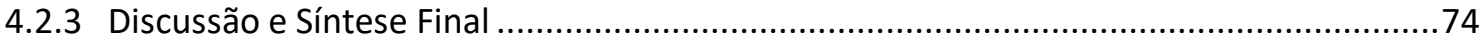

4.3 Aplicação e análise da atividade de investigação .....................................................................75

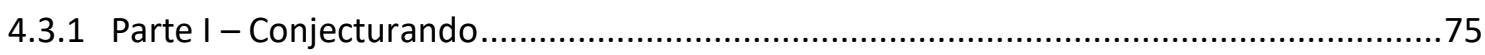

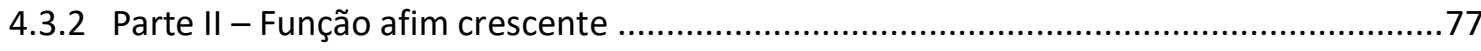

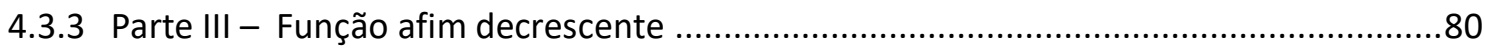

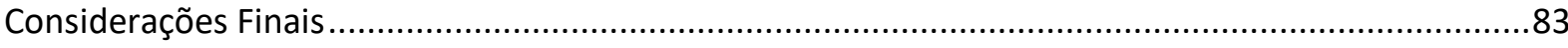

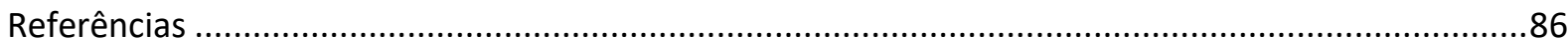

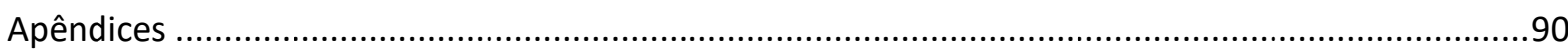




\section{Introdução}

Voltando os olhos para a matemática que praticamos em nossas aulas no Ensino Médio, imediatamente identificamos o tradicional estereótipo da matemática enquanto disciplina da escola básica: uma matéria desinteressante, inútil e acessível somente a poucos. Lidamos com questionamentos frequentes por partes dos alunos: Onde eu vou usar isto na minha vida? Por que tenho que aprender isto? Isso nos levou a refletir sobre o papel da matemática nas escolas.

Claro que, com o intuito de tornar a matemática significativa para o aluno, dispomos de várias estratégias para tratar do assunto em sala de aula. Trabalhar a matemática a partir de problemas do cotidiano, por meio de investigação matemática, por exemplo, seria abordá-la de uma forma provavelmente mais significativa para o aluno. $\mathrm{O}$ próprio exame nacional do ensino médio (ENEM) faz um forte apelo a esta tendência em suas questões, por muitas vezes demasiadamente contextualizadas, no sentido de situaçõesproblemas.

Entretanto, lembrando dos nossos primeiros anos no ensino superior, iremos, talvez, a contextualização poderia nos afastar ainda mais do aspecto demonstrativo da matemática. Com esse foco voltado para resoluções de problemas do cotidiano, aplicações de fórmulas e procedimentos aritméticos, "atualmente, verificamos, sem grande dificuldade, que no ensino fundamental e médio não se dá ênfase ao ensino de demonstrações em matemática" (ALMOULOUD et al., 2008, p.218).

Lembramos também da forte impressão gerada, tanto para os alunos recémformados quanto para as instituições de nível superior, sobre a fragilidade do ensino de matemática da escola básica. Segundo Motta $(2014$, p.3) as justificativas dadas pelas universidades para as dificuldades dos alunos no ensino superior "são, quase sempre, as mesmas: o Ensino Médio está cada vez pior, as escolas estão cada vez mais fracas, o ENEM é incapaz de selecionar os melhores alunos, etc". 
O que ocorre então é que na etapa de transição entre o Ensino Médio e o Superior é criada uma ponte aparentemente sem conexão em relação ao ensino de matemática. Se por um lado temos o Ensino Médio - de um modo geral - abordando a matemática com uma maior ênfase nos procedimentos aritméticos e algébricos, do ponto de vista prático, temos por outro lado o ensino superior, abordando uma matemática que exige um maior nível de abstração através de provas, demonstrações e o raciocínio lógico dedutivo.

De fato, a tensão entre a matemática formal no nível superior e a matemática informal na educação básica tem marcado o ensino, e pode servir para explicar um pouco as frequentes frustrações na passagem para o ensino superior. Mesmo que o aluno recém ingressado no ensino superior tenha uma afinidade com a área de exatas, não é incomum o sentimento de incapacidade quando Ihe é exigido um certo nível de formalização. Os altos índices de reprovações podem levá-lo a desmotivação, implicando em muitos casos mesmo que precocemente - a evasão do curso (BARUFI, 1999). A diferença entre a matemática ensinada nas universidades e a matemática ensinada na escola básica pode ser esquematizada da seguinte maneira:

Figura 1 - Diferenças entre a Matemática da Educação Básica e do Ensino Superior.

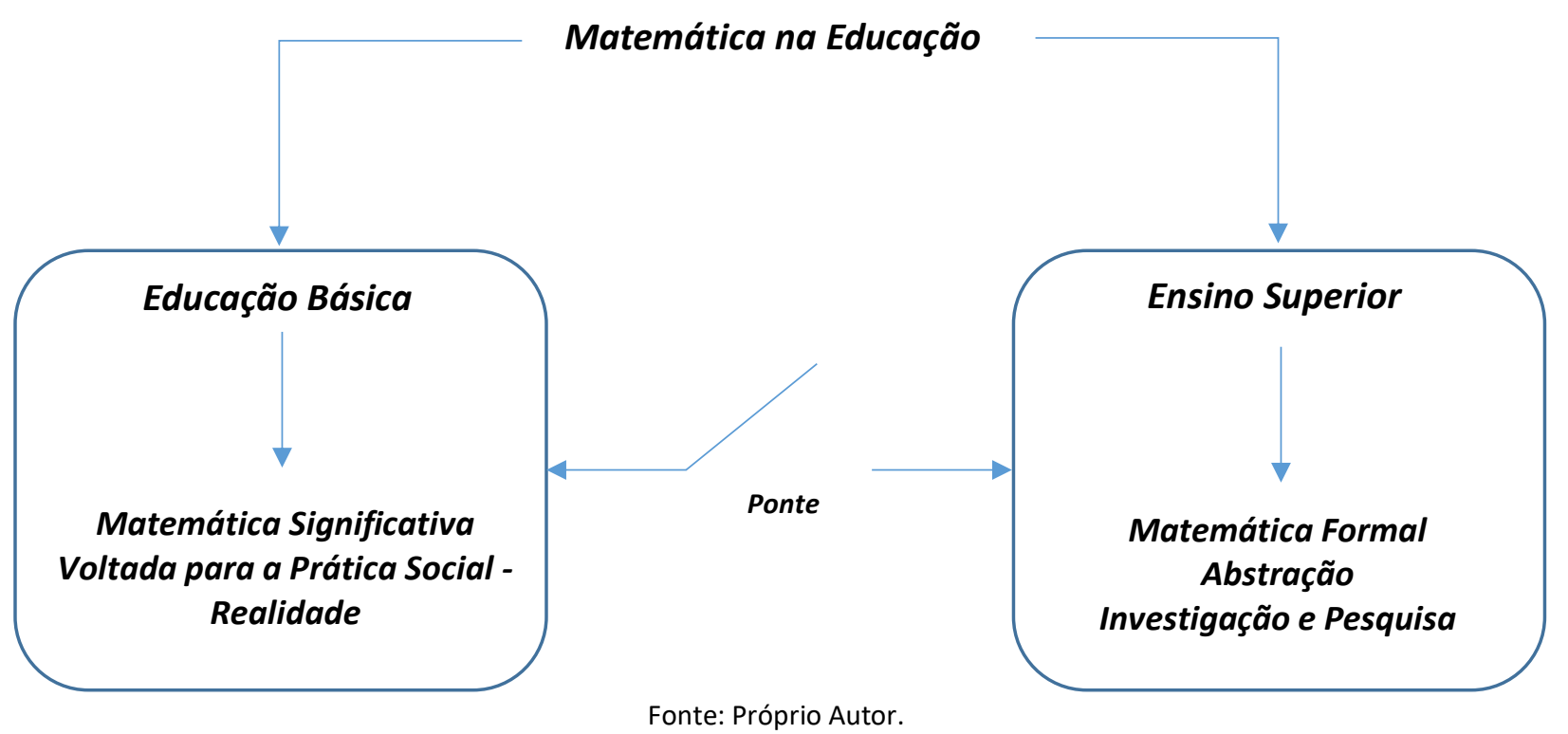


Então reforçar ainda mais o trabalho com problemas do dia a dia, buscar uma matemática mais prática e investigativa no Ensino Médio, poderia ajudar a torná-la mais significativa mas poderia também deixar os alunos menos preparados ainda para o prosseguimento dos estudos no ensino superior? Não daria para trazer aspectos de uma matemática mais demonstrativa para o Ensino Médio, sem que ela perca o aspecto desejado de ter significado para o aluno? São questões como essas que serviram de motivação para a realização deste trabalho, que irá estudar especificamente a seguinte questão de pesquisa:

- Como podemos, por meio da investigação matemática de um tema específico funções afins crescentes e decrescentes - trabalhar com demonstrações no ensino médio?

Para buscar possíveis respostas para as questões norteadoras deste trabalho, foi feito um breve histórico sobre a organização do pensamento matemático, observando em particular o episódio da mudança matemática na Grécia Antiga. O objetivo era entender um pouco como o processo de validação em matemática contribuiu para nosso desenvolvimento intelectual e consequentemente quais são os impactos no aspecto social.

Para discutir alguns problemas pertinentes aos anos iniciais de um curso de graduação na área de exatas, utilizamos como base artigos e trabalhos apresentados em congressos de matemática e de educação matemática. Alguns relatos destacaram pontos de vistas de alunos e professores de disciplinas iniciais do ensino superior - como Cálculo, Geometria e Álgebra Linear - e puderam nos auxiliar no estudo sobre as dificuldades de aprendizagem em matemática, na passagem do ensino médio para o superior.

Com base nos documentos oficiais, como as Leis de Diretrizes e Bases da Educação Nacional (LDBEN), as Diretrizes Curriculares Nacionais da Educação Básica (DCNEB) e o Pacto Nacional pelo fortalecimento do Ensino Médio (PNEM), fizemos um estudo sobre as finalidades do Ensino Médio na formação do aluno e o papel da matemática nessa formação, incluindo suas características específicas e suas formas de abordagem em sala de aula. 
Com esses estudos, foi possível realizar uma comparação entre objetivos e práticas de ensino de matemática dos dois níveis de ensino. Isso permitiu repensar a proposta que apresentamos a matemática do ensino médio, de tal forma a propor uma prática de ensino que permita aos alunos se aproximarem da matemática do ensino superior por meio da ideia de demonstração, trabalhada na perspectiva da investigação.

Ao final, foi apresentada a aplicação de uma sequência didática para alunos do ensino médio, com o intuito de verificar pontualmente a problemática desenvolvida neste trabalho. 


\section{Capítulo 1}

\section{A Matemática entre o Ensino Médio e o Ensino Superior}

\subsection{O Ensino Médio "oficial”}

O Ensino Médio no Brasil passou por um processo de desenvolvimento onde novas demandas sociais, que exigiam uma melhor qualificação dos jovens ingressantes no mercado do trabalho, surgiram com o intuito de manter a sustentação deste ciclo de desenvolvimento, até então vigente no país. Questões relacionadas a melhorias na acessibilidade e na qualidade da formação destes jovens tiveram uma maior relevância por parte da política educacional brasileira.

A Educação Básica, composto pelas etapas de Educação Infantil, Ensino Fundamental e Ensino Médio, tem como finalidade "desenvolver o educando, assegurar-lhe a formação comum indispensável para o exercício da cidadania e fornecer-lhe meios para progredir no trabalho e em estudos posteriores" (BRASIL, Senado Federal, 2005, p. 20).

Sob a ótica da educação em direitos humanos, é seu dever "[...] afirmar valores e estimular ações que contribuam para a transformação da sociedade, tornando-a mais humana, socialmente justa e, também, voltada para a preservação da natureza" (BRASIL, Secretaria de Direitos Humanos da Presidência da República, 2013, p.50).

Definidas as finalidades da Educação Básica, cada etapa assume responsabilidades específicas, com objetivos próprios, na qual se torna um processo formado por partes, mas com um propósito comum. 
A educação básica é um conceito mais do que inovador para um país que por séculos, negou, de modo elitista e seletivo, a seus cidadãos o direito ao conhecimento pela ação sistemática da organização escolar. Resulta daí que a educação infantil é a base da educação básica, o ensino fundamental é o seu tronco e o ensino médio é seu acabamento, e é de uma visão do todo como base que se pode ter uma visão consequente das partes (CURY, 2002, p. 171).

Desta forma o Ensino Médio - etapa em que consta os três últimos anos da educação básica - baseia-se na concepção de trabalho e prática da cidadania como objetivos de formação. As finalidades do Ensino Médio encontram-se descritas nas LDBEN, onde:

Art. 35. O ensino médio, etapa final da educação básica, com duração mínima de três anos, terá como finalidade:

i. a consolidação e o aprofundamento dos conhecimentos adquiridos no ensino fundamental, possibilitando o prosseguimento de estudos.

ii. a preparação básica para o trabalho e a cidadania do educando, para continuar aprendendo, de modo a ser capaz de se adaptar com flexibilidade a novas condições de ocupação ou aperfeiçoamento posteriores.

iii. o aprimoramento do educando como pessoa humana, incluindo a formação ética e o desenvolvimento da autonomia intelectual e do pensamento crítico.

iv. a compreensão dos fundamentos científico-tecnológicos dos processos produtivos, relacionando a teoria com a prática, no ensino de cada disciplina (BRASIL, Senado Federal, 2005, p.18).

Atualmente o Ensino Médio tem ocupado um papel de destaque nas discussões sobre educação. Tanto sua estrutura quanto seu conteúdo geralmente não atraem mais os jovens, estando longe de atender as necessidades atuais dos estudantes.

O Ensino Médio no Brasil tem se constituído, ao longo da história da educação brasileira, como o nível de maior complexidade na estruturação de políticas 
públicas de enfrentamento aos desafios estabelecidos pela sociedade moderna, em decorrência de sua própria natureza enquanto etapa intermediária entre o Ensino Fundamental e a Educação Superior e a particularidade de atender a adolescentes, jovens e adultos em suas diferentes expectativas frente à escolarização (BRASIL. Ministério da Educação, 2009, p.3).

Com o envolvimento do Ministério da Educação (MEC), Conselho Nacional de Educação e Movimentos (CONSED) e universidades brasileiras, o Pacto Nacional pelo fortalecimento do Ensino Médio (PNEM), instituído em 2013, tem como objetivo elevar o padrão de qualidade do Ensino Médio brasileiro, através de ações como a implantação das Diretrizes Curriculares Nacionais da Educação Básica (DCNEB), formação continuada dos professores e coordenadores pedagógicos de Ensino Médio, bem como o redesenho curricular do Ensino Médio.

Ainda de acordo com as DCNEB, as finalidades legais, propostas pelo artigo 35 das LDBEN, definem a identidade da escola no âmbito de quatro funções:

\footnotetext{
I - consolidação dos conhecimentos anteriormente adquiridos;

II - preparação do cidadão para o trabalho;

III - implementação da autonomia intelectual e da formação ética;

IV - compreensão da relação teoria e prática (BRASIL, Ministério da Educação, 2013, p.170).
}

Sendo assim, o Ensino Médio, em todas as suas formas de oferta e organização, baseia-se no conceito da formação integral do estudante, que tem como base, o trabalho como princípio educativo, a pesquisa como fundamento pedagógico e a integração entre educação e as dimensões do trabalho, da ciência, da tecnologia e da cultura como base da proposta e do desenvolvimento curricular (BRASIL, Ministério da Educação, 2013).

Kuenzer (2000, p.36) chama a atenção para as finalidades e os objetivos do Ensino Médio, nas quais se resumem "no compromisso de educar o jovem para participar 
política e produtivamente do mundo das relações sociais concretas, pelo desenvolvimento da autonomia intelectual e da autonomia ético-política".

Assim, para que se alcance tais finalidades, entende-se que, além do projeto político pedagógico, uma parte significativa deste trabalho é remetida a estruturação do currículo, que entende como sendo

[...] a seleção dos conhecimentos historicamente acumulados, considerados relevantes e pertinentes em um dado contexto histórico, e definidos tendo por base o projeto de sociedade e de formação humana que a ele se articula; se expressa por meio de uma proposta pela qual se explicitam as intenções da formação, e se concretiza por meio das práticas escolares realizadas com vistas a dar materialidade a essa proposta (BRASIL, Ministério da Educação, 2013, p.179).

Desta forma o currículo pode-se concretizar de acordo com diferentes concepções, entretanto, segundo as DCNEB, tem como objetivo orientar a organização do processo educativo escolar.

Suas diferentes concepções, com maior ou menor ênfase, refletem a importância de componentes curriculares, tais como os saberes a serem ensinados e aprendidos; as situações e experiências de aprendizagem; os planos e projetos pedagógicos; as finalidades e os objetivos a serem alcançados, bem como os processos de avaliação a serem adotados. Em todas essas perspectivas é notável o propósito de se organizar e de se tornar a educação escolar mais eficiente, por meio de ações pedagógicas coletivamente planejadas (BRASIL, Ministério da Educação, 2013, p.180).

A escolha das disciplinas que fazem parte do currículo do Ensino Médio, tem como propósito tornar eficiente o processo educativo, de modo que as finalidades propostas pela LDBEN sejam alcançadas.

Além de uma seleção criteriosa de saberes, em termos de quantidade, pertinência e relevância, e de sua equilibrada distribuição ao longo dos tempos de organização 
escolar, vale possibilitar ao estudante as condições para o desenvolvimento da capacidade de busca autônoma do conhecimento e formas de garantir sua apropriação (BRASIL, Ministério da Educação, 2013, p.180).

\section{Para tal composição, o artigo 26 das LDBEN determina que}

Os currículos do ensino fundamental e médio devem ter uma base nacional comum, a ser complementada, em cada sistema de ensino e estabelecimento escolar, por uma parte diversificada, exigida pelas características regionais e locais da sociedade, da cultura, da economia e da clientela.

Divididos em quatro áreas do conhecimento pela atual legislação Linguagens, Matemática, Ciências da Natureza e Ciências Humanas - os componentes curriculares que estruturam o Ensino Médio são:

I - o estudo da Língua Portuguesa e da Matemática, o conhecimento do mundo físico e natural e da realidade social e política, especialmente do Brasil; II - o ensino da Arte, especialmente em suas expressões regionais, de forma a promover o desenvolvimento cultural dos estudantes, com a Música como seu conteúdo obrigatório, mas não exclusivo;

III - a Educação Física, integrada à proposta pedagógica da instituição de ensino, sendo sua prática facultativa ao estudante nos casos previstos em Lei; IV - o ensino da História do Brasil, que leva em conta as contribuições das diferentes culturas e etnias para a formação do povo brasileiro, especialmente das matrizes indígena, africana e europeia;

V - o estudo da História e Cultura Afro-Brasileira e Indígena, no âmbito de todo o currículo escolar, em especial nas áreas de educação artística e de literatura e história brasileiras;

$\mathrm{VI}$ - a Filosofia e a Sociologia em todos os anos do curso;

VII - uma língua estrangeira moderna na parte diversificada, escolhida pela comunidade escolar, e uma segunda, em caráter optativo, dentro das disponibilidades da instituição (BRASIL, Ministério da Educação, 2013, p.180). 
Entretanto a realidade atual do ensino médio brasileiro aparenta não estar em consonância das necessidades atuais dos jovens. Esta divergência é posta à tona no documentário Nunca me Sonharam (2017), que de acordo com relatos de alunos do ensino médio de escolas públicas de várias regiões do Brasil o ensino proposto atualmente não está sendo significativo em suas vidas.

Segundo Salatino (2014, p.27) "os jovens experimentam nesse período a ausência de um sentido de caráter imediato e utilitário em seus estudos". Se por um lado o diploma do ensino médio não representa muito valor para ingressar no mercado de trabalho pois não the fornece uma formação específica, por outro os conteúdos e suas formas de apresentação estão longe de um ser um fator motivador para que os alunos se interessem pelos estudos.

As classes populares se relacionam com a instituição escolar como que motivadas pela por uma espécie de "lógica da necessidade". Desta maneira, o estabelecimento de uma relação com um conhecimento que não possui uma utilidade prática e imediata teria uma maior dificuldade de se dar num contexto em que se não possui uma utilidade prática e imediata teria uma maior dificuldade de se dar num contexto em que não se possui um ethos ${ }^{1}$ de ascensão social através da escola, ethos característico do estilo de vida das camadas médias da sociedade. Salatino $(2014$, p.28)

Ouvir as opiniões dos jovens sobre como podemos melhorar o cenário atual do ensino médio é, segundo o documentário, uma das chaves para que a escola contribua de forma significativa em suas vidas. Eles pedem por um ensino motivador, que os façam raciocinar e serem críticos quanto aos tópicos estudados. A simples transmissão dos conhecimentos é um dos principais fatores que levam aos alunos a não enxergarem um sentido para a escola e, consequentemente, não quererem participar do contexto escolar.

Com base nestes fatos, uma das áreas mais afetadas pela falta de interesse dos alunos é a matemática. Um ensino onde a matemática resume-se a aplicação de

${ }^{1}$ conjunto dos costumes e hábitos fundamentais, no âmbito do comportamento e da cultura, característicos de uma determinada coletividade, época ou região. 
fórmulas e cálculos meramente mecânicos, raramente fará com que o aluno na idade da juventude desperte o interesse pela disciplina.

Desta forma, refletir sobre qual é o papel da matemática no ensino médio, é importante para que possamos entender um pouco mais sobre como ela pode contribuir na formação integral do aluno e, ao mesmo atempo, atender as necessidades atuais dos jovens.

\subsection{A Matemática no Ensino Médio}

Como citado anteriormente, o estereótipo criado ao longo da história sobre a matemática como uma ciência acessível somente a poucos, entra em conflito com a relevância que ela possui na estrutura do Ensino Médio. Desta forma nos faz refletir sobre a seguinte questão: Qual é o papel que da Matemática no Ensino Médio?

De acordo com BRASIL (Secretária de Educação Básica, 2014), uma das principais finalidades da Matemática do Ensino Médio é a de desenvolver as capacidades de formular e resolver problemas, de comunicar, de analisar criticamente uma situação, considerando suas diferentes possibilidades ou restrições.

O ensino de Matemática com tal foco favorece a formação de cidadãos aptos a realizar intervenções na realidade, a partir da compreensão de problemas e situações da sociedade atual (BRASIL, Secretária de Educação Básica, 2014, p.19).

Segundo os Parâmetros Curriculares do Ensino Médio (PCNEM) a matemática assume dois valores nesta etapa de escolarização: O primeiro, como valor formativo, que ajuda a estruturar o pensamento e o raciocínio dedutivo.

Em seu papel formativo, a Matemática contribui para o desenvolvimento de processos de pensamento e a aquisição de atitudes, cuja utilidade e alcance transcendem o âmbito da própria Matemática, podendo formar no aluno a 
capacidade de resolver problemas genuínos, gerando hábitos de investigação, proporcionando confiança e desprendimento para analisar e enfrentar situações novas, propiciando a formação de uma visão ampla e científica da realidade, a percepção da beleza e da harmonia, o desenvolvimento da criatividade e de outras capacidades pessoais (BRASIL, Secretária de Educação Média e Tecnológica, 2000 p.40).

O segundo, como um valor instrumental, por ser uma ferramenta que serve para a vida cotidiana e para muitas tarefas específicas em quase todas as atividades humanas.

No que diz respeito ao caráter instrumental da Matemática no Ensino Médio, ela deve ser vista pelo aluno como um conjunto de técnicas e estratégias para serem aplicadas a outras áreas do conhecimento, assim como para a atividade profissional. Não se trata de os alunos possuírem muitas e sofisticadas estratégias, mas sim de desenvolverem a iniciativa e a segurança para adaptá-las a diferentes contextos, usando-as adequadamente no momento oportuno (BRASIL, Secretária de Educação Média e Tecnológica, 2000 p.40).

Agregando-se ao valor formativo e instrumental da matemática, a importância da demonstração e validação de conjecturas são citadas nos PCNEM, onde a matemática também deve ser vista como ciência, com suas características estruturais específicas.

É importante que o aluno perceba que as definições, demonstrações e encadeamentos conceituais e lógicos têm a função de construir novos conceitos e estruturas a partir de outros e que servem para validar intuições e dar sentido às técnicas aplicadas (BRASIL, Secretária de Educação Média e Tecnológica, 2000 p.41).

O Guia de Livros Didáticos de Matemática do Ensino Médio (PNLDEM), publicado em 2015, apresenta resenhas de 6 coleções aprovadas com o objetivo de 
contribuir na escolha do texto didático que apoiará a formação dos alunos do ensino médio. O PNLDEM é bem enfático na importância de ampliação, organização e aprofundamento dos conhecimentos matemáticos adquiridos pelo aluno no ensino fundamental. Em seu texto é destacado a importância de se ter um ensino de matemática, no ensino médio, que aborde os conceitos de matemática desenvolvida nas universidades. O PNLDEM ainda enfatiza a importância da prova em matemática raciocínio lógico dedutivo, onde cita que é o único método aceito na comunidade científica para a comprovação de um fato matemático e deve fazer parte do ensino de matemática nesta última etapa da educação básica.

Os conceitos de axioma, definição, teorema e demonstração são o cerne desse método e, por extensão, passaram a ser, para muitos, a face mais visível da Matemática. Trata-se de um método de validação do fato matemático, muito mais do que um método de descoberta ou de uso do conhecimento matemático. $\mathrm{Na}$ construção efetiva desse saber, faz-se uso permanente da imaginação, de raciocínios indutivos ou plausíveis, de conjecturas, de tentativas, de verificações empíricas, enfim, recorre-se a uma variedade complexa de outros procedimentos (BRASIL, Ministério da Educação, 2014, p.12).

Entretanto parece existir uma cultura recém-criada entre os profissionais da educação da Escola Básica de que a matemática do Ensino Médio somente é significativa para os alunos se for possível relacionar com alguma aplicação prática. Também por parte dos alunos, existe uma crença de sempre questionar a aprendizagem de um conteúdo matemático. Se não houver uma resposta imediata do professor justificando o conteúdo específico com alguma aplicação prática, então o aluno julga aquele conteúdo inútil e imediatamente abandona o seu aprendizado.

Assim, de um modo geral, acreditamos que a matemática do Ensino Médio deve ser apresentada sempre com uma justificativa apoiada na aplicação prática, concreta, criando situações-problemas do mundo real que muitas vezes sequer existem. 
Este comportamento pouco contribui para a formação integral do aluno. Além de limitar seu desenvolvimento intelectual - pois sempre espera que o professor passe uma fórmula para resolver um problema - criamos uma matemática escolar que, de acordo com BRASIL (Secretária de Educação Básica, 2014) privilegia os cálculos e a memorização, focado em técnicas operatórias e prescrição de procedimentos, sem justificativas.

É importante salientar que contextualização e interdisciplinaridade são, muitas vezes, reduzidas ao uso de situações-problema ou exemplos simples em atividades de Matemática que envolvem conceitos de outros diversos conhecimentos de diferentes áreas para a compreensão curriculares/disciplinas, sem estabelecer relações mais consistentes entre eles. Assim, não podemos chamar de contexto um problema sobre movimento retilíneo uniforme ou velocidade média, cujo único objetivo é que o estudante escreva e resolva uma equação. Contexto não é mero pretexto. No âmbito do que estamos propondo aqui, é preciso que se reconheça a diferença entre exemplos simples e contextos que requerem a negociação conjunta de diversos pontos de vista, intrinsecamente pertinentes a mais de um componente ou área. Ou seja, verdadeiros contextos, no sentido de abordagens didático-pedagógicas com potencial de favorecer aprendizagens significativas, precisam envolver necessariamente diversos conhecimentos de diferentes áreas para a compreensão mais abrangente de uma situação-problema relevante (BRASIL Secretária de Educação Básica, 2014, p.13).

Este fato vai ao encontro das críticas dos alunos em relação ao atual panorama do ensino médio, apresentadas no capítulo anterior. Por muitas vezes, na tentativa de tornar o ensino de matemática significativo, entendemos como sendo "dar significado do sentido prático", não nos atentando que estamos desenvolvendo a mesma prática tradicional que já não atende as necessidades atuais dos jovens.

Um outro ponto de vista é que essa tendência foi fortemente adotada nos exames vestibulares ao redor do Brasil. O próprio Exame Nacional do Ensino Médio (ENEM), porta de entrada para diversas universidades, baseia-se em questões na qual a matemática encontra-se em um problema do cotidiano, onde de certo modo ou de outro, devemos aplicar fórmulas e calcular o resultado correto. 
Essas práticas desenvolvidas ao longo do ensino médio, refletem diretamente nos anos iniciais do ensino superior. Mesmo o aluno conseguindo uma nota satisfatória no ENEM ou em vestibulares específicos que permitem o ingresso em universidades, as defasagens apontadas por professores e alunos em relação a capacidade matemática e falta de autonomia, indiciam a pequena contribuição que a matemática agrega na formação dos alunos do ensino médio.

\subsection{A matemática na transição para o Ensino Superior}

A preocupação com o ingresso em uma universidade é tema pertinente no período que antecedem a formação do aluno de Ensino Médio. No Brasil, o ingresso em um curso de nível superior, principalmente em instituições públicas, é um sinônimo de sucesso em todas as classes sociais. Contudo, este momento, repleto de dúvidas e tomadas de decisões marca um ponto, considerados por muitos, como crucial para a vida tanto no aspecto pessoal, quanto no profissional.

Porém, a transição do nível secundário para o universitário trata-se de um processo complexo e multidimensional. Este processo requer do aluno um desenvolvimento de conjunto de novas competências frente a novos desafios acadêmicos, cognitivos, pessoais, sociais e afetivos.

Com efeito, podemos considerar o ajustamento do estudante associado ao efeito interativo de três blocos de variáveis: (i) as sus competências para enfrentar as mudanças proporcionadas pelas universidades; (ii) os suportes sociais e os recursos a que pode recorrer nesta transição por parte da família, dos pares e dos serviços acadêmicos disponíveis; e (iii) o tipo de nível de exigências adaptativas colocadas pela própria Universidade e pelo novo contexto de vida (ALMEIDA et al., 2000).

Inserido neste complexo processo, as dificuldades encontradas no contexto acadêmico, pelos alunos que escolhem a carreira de Matemática, Física ou Engenharia - e outros cursos da área de exatas, que contenham disciplinas de matemática em sua grade curricular - se tornam evidentes nos primeiros anos da graduação. Motta (2014) afirma que, nos cursos de graduação oferecidos pelas universidades brasileiras, nos quais possuem 
disciplinas de Cálculo Diferencial e Integral em sua grade curricular, são frequentes os altos índices de reprovação. Não somente é apontado este problema, como outros surgem em decorrência tais como receio frente a capacidade matemática, motivação para prosseguimento dos estudos e, como desfecho dessa cadeia, a evasão de estudantes dos cursos de graduação, que de maneira precoce são levados a crer que, talvez, tenham feito a escolha profissional errada.

Porém, este fato não é uma particularidade a âmbito nacional. Mudanças nos currículos de matemática do ensino superior, menor número de matrículas de estudantes em cursos de graduação em matemática e um alto número de alunos que permanecem nos anos iniciais da graduação provocaram algumas preocupações de âmbito internacional sobre a capacidade matemática dos estudantes ingressantes em universidades e vem sendo tema de debates em Congressos Internacionais de Educação Matemática.

A diminuição dos níveis de competência matemática (dos alunos recém-formados no ensino médio) tem sido relatados em relação à simplicidade técnica, capacidade analítica e percepções sobre o rigor e o papel da prova em matemática (GILL² et al., 2010, p. 1, apud DRUCK et al. 2012, tradução nossa).

Com base no relatório sobre questões pertinentes a transição do ensino secundário para a matemática universitária - apresentado no 12 Congresso Internacional de Educação Matemática (ICME-12), realizado no ano de 2012, em Seul, Coreia do Sul onde foram apresentados resultados de uma pesquisa contendo 79 membros de departamentos de matemática em universidades de 21 países, são evidenciadas dificuldades em relação aos conceitos e formas de fazer matemática nesta etapa de transição.

Segundo a pesquisa, mais da metade dos professores universitários entrevistados de diversos países como EUA, Nova Zelândia, África do Sul e Brasil, que lecionam disciplinas de matemática como cálculo álgebra linear, análise real, teoria dos números e geometria, apontam que a abordagem dos conteúdos de matemática em

\footnotetext{
${ }^{2}$ GILL, O. et al. Trends in performance of science and technology students (1997-2008) in Ireland. International Journal of Mathematical Education in Science and Technology, 41(3), 323-339. doi:10.1080/00207390903477426. 2010.
} 
disciplinas de primeiro ano assume ambas posturas: Simbólica/Processual e Axiomática/Formal, variando de acordo com o curso.

Gráfico 1 - A abordagem da matemática no primeiro ano de sua universidade.

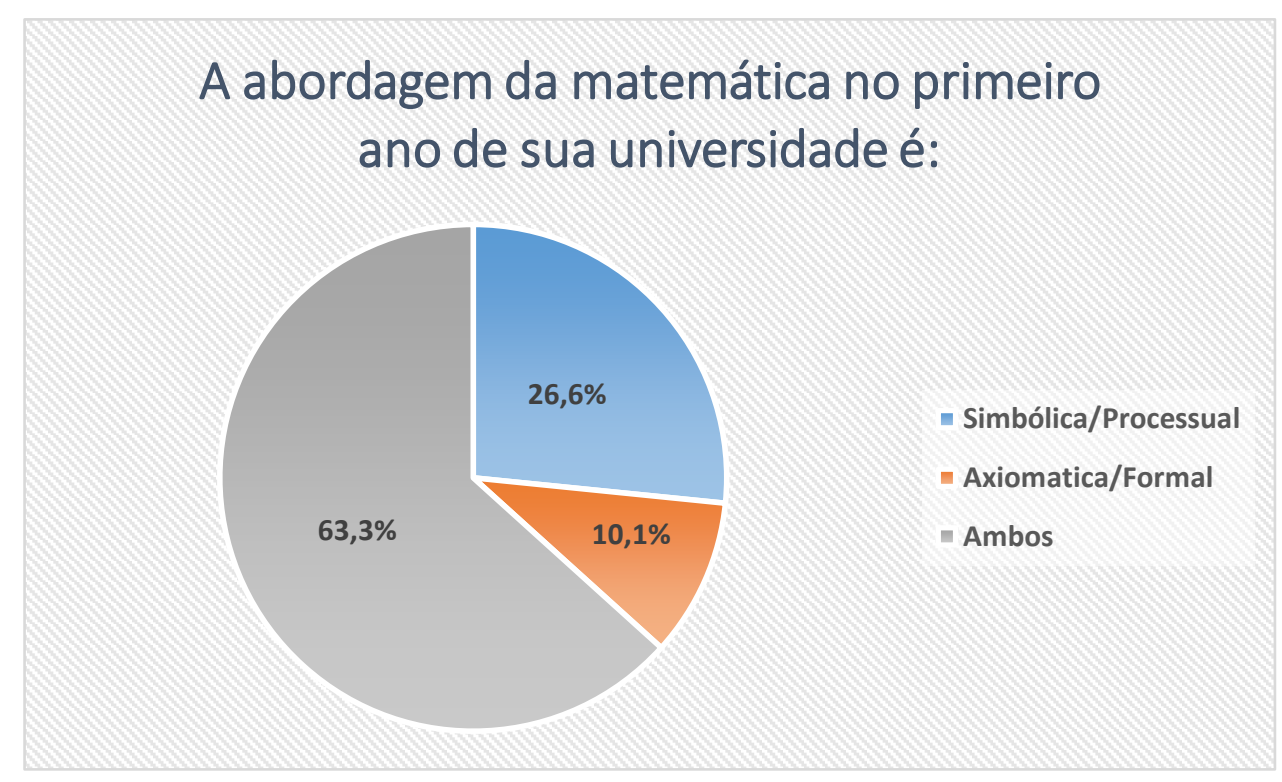

Fonte: ICME-12

Apesar de somente uma pequena parte dos professores realizarem uma abordagem exclusivamente Axiomática/Formal, em disciplinas das séries iniciais, os problemas em relação a maturidade matemática dos alunos provindos do Ensino Médio são destacados pelos professores. Em quase unanimidade, os professores concordam que os estudantes ingressantes nos cursos de graduação possuem problemas relacionados a matemática nesta etapa de transição. Comentários em relação a falta de compreensão das habilidades de matemática básica e enorme lacuna entre a demasiada matemática processual do ensino médio e a matemática conceitual da universidade, descrevem o censo comum dos professores universitários em relação a falta de eficácia em relação a preparação dos alunos na escola básica.

Além disso, os professores universitários citam que é comum ter de lidar com os equívocos que os alunos desenvolvem na escola secundária, sendo necessário rever conceitos e procedimentos a partir de um ponto de vista matemático considerado adequado para o nível de graduação. Estes equívocos apontados pelos professores podem estar relacionados com o tipo de abordagem dos conteúdos de matemática no Ensino Médio. 
Uma abordagem onde pede-se a comprovação de uma fórmula, onde envolva a argumentação por parte dos alunos nem sempre é trabalhada pois outras tendências de educação matemática estão em evidência quando fala-se de ensino de matemática básica.

Este perfil traçado pelos professores dos recém-ingressados nos cursos de graduação acabou levando as universidades a repensarem seus cursos iniciais, fazendo alterações ou criarem novas disciplinas para suplementar a deficiência no aprendizado de matemática do Ensino Médio. Ao questionarem se "O conteúdo de seus cursos de matemática do primeiro teve alterações nos últimos 5 anos? Quais os tipos? ", 35 respostas afirmaram que houve alterações, e dentre elas, 17 responderam que foram retirados tópicos complexos e introduzindo tópicos de matemática do ponto de vista prático, além do uso de softwares e calculadoras gráficas.

Segundo o relatório, os pontos de vista dos professores universitários mostram que, entre as mudanças que poderiam serem feitas no Ensino Médio, requerem uma maior atenção:

i. incentivar os alunos a pensar de forma independente e abstratamente;

ii. melhorar a formação dos professores secundários de modo que tenha a capacidade de proporcionar um ensino que não tenha como foco principal a matemática baseada em testes e procedimentos padronizados.

iii. Tratar a matemática do ensino médio de forma que aproxime da matemática universitária

Em conexão com o ICM (International Congress of Mathematicians) Guzmáni et al. (1998) identificam algumas dificuldades relevantes provenientes desta etapa de transição e examinam suas possíveis causas, através de uma pesquisa envolvendo não somente os professores, mas também os alunos de diversos cursos de graduação de universidades do Canadá, França e Espanha. 
No que diz respeito a visão dos estudantes, 610 alunos, a maioria recém ingressados em suas respectivas universidades, responderam a um questionário sobre a forma como os professores apresentam a matemática no nível universitário e a organização em sala de aula; mudanças nas formas de pensar matematicamente; e falta de ferramentas apropriadas para a aprendizagem.

Desta forma, parece existir um senso comum por parte dos estudantes em relação a uma maior abstração da matemática universitária quando comparada com matemática do ensino médio. Além disso, consideram a abordagem relacionada ao uso da demonstração para o desenvolvimento da matemática um procedimento de grau elevado de dificuldade. Comentários como "não estou acostumado a provas" e "que na escola básica eu nunca aprendi a realizar uma prova" são destacados e reforçam a dificuldade frente ao novo modo de fazer matemática no ensino superior.

Quando questionados em relação a prática dos professores universitários, os alunos destacam algumas características como muitos professores não se importarem se os alunos aprenderam ou não um determinado assunto; citam que possuem dificuldades em transmitir para o aluno fatos considerados evidentes e que muitas vezes não entendem (ou aceitam) que os alunos não entendem.

Em contrapartida, segundo a visão dos professores universitários, a transição do ensino médio para o universitário é classificada como problemática para a maioria dos estudantes. Além da defasagem existente em termos da matemática, existe uma frequente insatisfação em relação a falta de maturidade e hábitos construídos ao longo do ensino médio, como por exemplo a dependência do professor para aprender.

(os professores universitários) lamentam os hábitos de pensamento e trabalho de seus alunos em matemática, sua falta de organização e de rigor matemático, bem como a dificuldade em adquirir e consolidar o conhecimento através do trabalho pessoal. A aquisição de um certo nível de autonomia na aprendizagem é muitas vezes vista pelos professores universitários como o principal obstáculo na passagem do ensino médio para o superior. (GUZMÁNI et al. 1998, p. 5, tradução nossa). 
Desta forma, uma outra preocupação por parte dos professores surge nos anos iniciais de um curso universitário - A autonomia dos alunos. Segundo as Leis de Diretrizes e Bases da Educação Nacional (LDBEN) um dos objetivos do ensino superior

É incentivar o trabalho de pesquisa e investigação científica, visando o desenvolvimento da ciência e da tecnologia e da criação e difusão da cultura, e, desse modo, desenvolver o entendimento do homem e do meio em que vive (BRASIL, Senado Federal, 2005, p. 20).

Geralmente os professores que lecionam as disciplinas de matemática em universidades tem como atividade principal a pesquisa. Desta forma, ao lecionar, muitos a trazem como bagagem cultural a acabam utilizando como recurso pedagógico em sala de aula.

Entretanto, para realizar atividades de pesquisa e investigação, os alunos precisam ter hábitos que raramente são desenvolvidos no ensino médio, tais como: obter informações não somente do professor; a prática da leitura; assistir e tomar notas durante uma palestra; fazer planos de estudo; e quais questões perguntar a si mesmo, antes que o professor as pergunte (GUZMÁNI et al., 1998).

O problema fundamental é que a maioria dos nossos atuais alunos do ensino médio não sabem como aprender ou mesmo o que significa aprender (a fortiori a entender) algo. Em efeito, eles se formam no ensino médio sentimento de que a aprendizagem deve chegar até eles de seus professores [...]. Que os alunos também devem aprender por conta própria, fora da sala de aula, é a principal característica que distingue a faculdade do ensino médio (ZUCKER ${ }^{3}$ 1996, apud GUZMÁNI et al., 1998, p.751, tradução nossa).

${ }^{3}$ Zucker, S., "Teaching at the university level." Notices of the American Ailathematical Society 43 (1996) 863-865. 
De um modo geral, os relatórios permitem identificar diversos problemas nesta etapa de transição. Em termos de Brasil, a problemática da defasagem entre os conhecimentos básicos que o aluno traz do ensino médio (tanto técnico quanto postural) e a expectativa das universidades, perante as opiniões dos professores, parece gerar uma impressão da fragilidade do ensino médio na formação do indivíduo.

a universidade vem falhando nos mesmos pontos em que acusava a escola de ser incapaz, repetindo as práticas que, em tese, estariam sendo encaminhadas, na escola, pelos seus próprios alunos egressos, summa cum laude. Penso que o pequeno recorte apresentado já é suficiente para indicar a necessidade da universidade rediscutir parcialmente alguns dos seus currículos e se aproximar da escola e das discussões atuais acerca da construção de um currículo nacional, a fim de contribuir na importante transição entre a Educação Básica e o Ensino Superior. Para isso, precisará conhecer a si própria e a realidade da escola (MOTTA, 2014, p.5).

Assim, entendemos que tornar a matemática significativa para um aluno do ensino médio é agregar na formação integral do aluno tornando-a um forte instrumento que os levem a desenvolver capacidades como argumentar, validar, refutar, investigar, dessa forma desenvolvendo o raciocínio lógico e o espírito crítico e ao mesmo tempo proporcionar uma matemática que se adeque as necessidades atuais dos jovens.

Desta forma, as atividades de investigação que envolvam conteúdos internos da matemática podem ser uma excelente ferramenta que aproxime a matemática do ensino médio à matemática do ensino superior minimizando a ponte entre os dois níveis sem perder de foco a formação integral do aluno do ensino médio, colocando o aluno como produtor do conhecimento e assim podendo proporcionar uma melhor preparação ao aluno que deseje ingressar em uma universidade. 


\section{Capítulo 2}

\section{A investigação matemática em sala de aula.}

\subsection{Investigação matemática segundo Ponte}

Em nossa atual sociedade, é comum relacionar a atividade de investigação a uma certa comunidade científica, que envolve o uso de metodologias sofisticadas e com recursos que somente as classes etilistas praticam (PONTE, 2003). Sendo assim, diversos mitos foram criados em função da palavra investigar, entre os quais destacam-se:

- Investigar é uma actividade transcendente, que envolve o uso de metodologias sofisticadas, requerendo recursos especiais e uma longa preparação prévia.

- Investigar é uma actividade reservada a um grupo especial de pessoas, os "investigadores profissionais".

- Ensinar e investigar são duas actividades contraditórias, que não se conseguem fazer em simultâneo sem comprometer a qualidade de uma ou outra (PONTE, 2003, p.1).

É fato que muitas universidades dedicam boa parte de suas forças ao trabalho investigativo. Aliás, conforme citado anteriormente, uma das finalidades que remete a Educação Superior é incentivar o trabalho de pesquisa e investigação. Porém outras finalidades fazem parte da formação superior, entre elas atividades referentes a ensino.

Embora tanto as atividades de investigação, quanto as atividades de ensino ${ }^{1}$, estarem contidas em um mesmo contexto, os mitos citados acimas levam a todos os envolvidos a crerem que são atividades diferenciadas.

\footnotetext{
${ }^{1}$ Atividades de cunho educativo; que envolvem o processo de ensino e aprendizagem
} 
De um modo resumido, nas atividades de investigação e pesquisa, o personagem é o investigador, que descobre ou inventa algo, enquanto que o professor, em um outro contexto, ensina tais conhecimentos, que são aprendidos pelos alunos (PONTE, 2003).

Figura 2 - Representação das relações entre ensino e investigação.

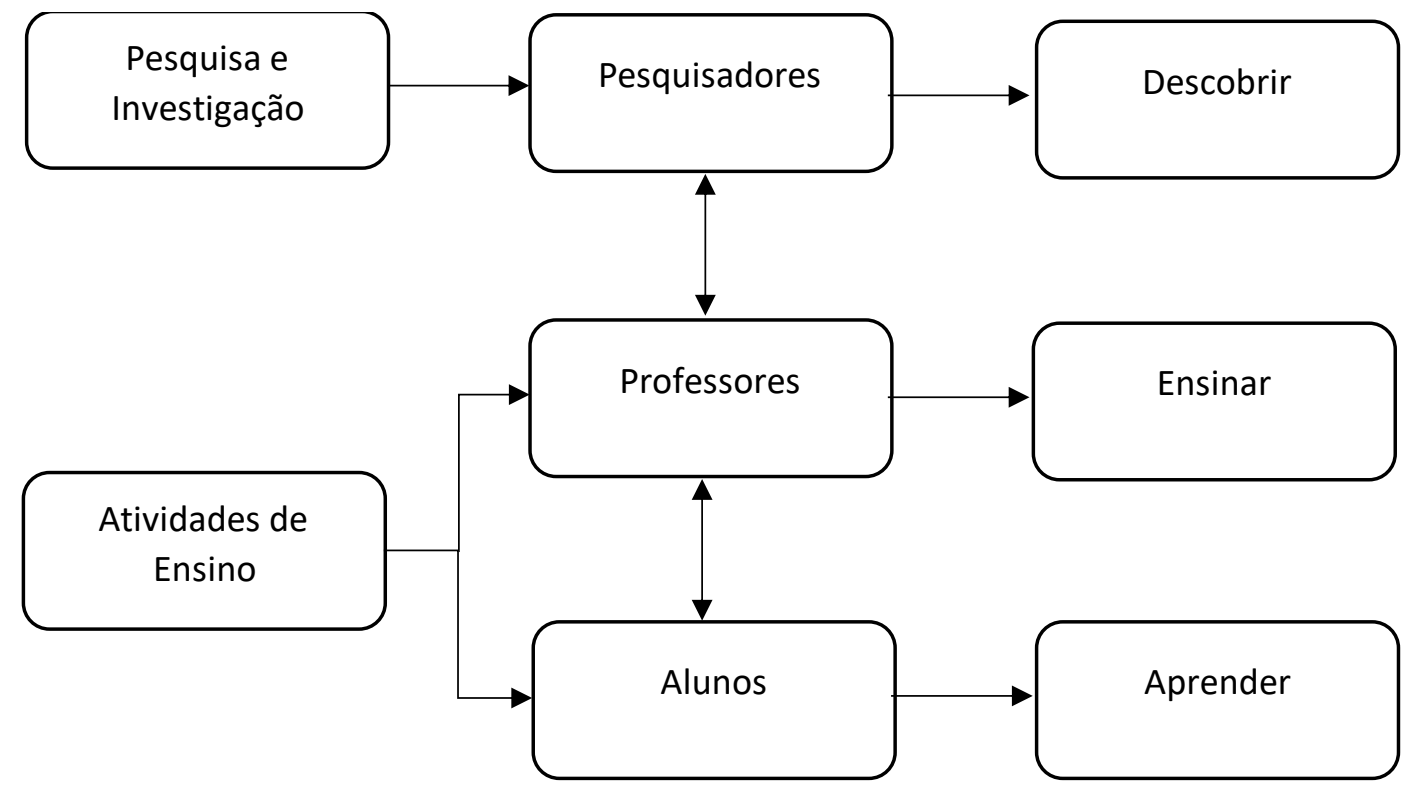

Fonte: Próprio Autor.

Em muitos casos, principalmente nas universidades, acontece que o professor exerce uma função de mediador no ciclo descobrir-ensinar-aprender, até então entendidas como disjuntas. Em contrapartida a esta ideia, Ponte (2003) cita uma estreita relação entre as duas atividades, com argumentos baseados no fato de quem investiga está a procura por aprender e quem aprende pode ter muito interesse em investigar.

(...) investigar não é mais do que procurar conhecer, procurar compreender, procurar encontrar soluções para os problemas com nos deparamos. Trata-se de uma capacidade de primeira importância para todos os cidadãos e que deveria permear todo o trabalho da escola, tanto dos professores como dos alunos (PONTE, 2003, p.2). 


\subsection{Uma metodologia de investigação matemática}

Quando estamos realizando um planejamento de aula, fatores como tipo da tarefa, características dos alunos, condições de trabalho oferecidos influenciam diretamente na estratégia de ensino a ser aplicada em sala de aula.

A consideração de diferentes tipos de tarefas, papéis e padrões de comunicação fornece uma caracterização dos dois principais estilos de práticas de ensino de Matemática que encontramos hoje nas salas de aula em todo o mundo em diferentes níveis de ensino (PONTE, 2010, p.24).

Desta forma, Ponte (2010) identifica dois estilos de práticas pedagógicas: 0 ensino directo ${ }^{2}$ e o ensino-aprendizagem exploratória. Independente do estilo adotado, tanto o papel do professor quanto o do aluno se sobressaem sobre os demais aspectos, de modo que se torne bem claro o que o professor irá fazer e que se espera que o aluno faça.

No ensino direto, Ponte (2005) define o papel principal do professor como detentor e transmissor do conhecimento, onde apresenta situações e exemplos da forma mais clara, atrativa e sistematizada possível. Por outro lado, o aluno assume uma postura consideravelmente passiva no processo de aprendizagem, onde suas principais funções são de ouvir, assimilar e realizar exercícios.

É de notar que esta exposição da matéria pode ser realizada tanto em aulas magistrais, em que apenas fala o professor, como em aulas mais informais, em que o professor vai fazendo aqui e ali perguntas aos alunos, que ajudam a ilustrar um ou outro ponto, e contribuem para criar um ambiente mais participado. No entanto, tais perguntas não presumem da parte dos alunos um envolvimento especial, cabendo-lhes essencialmente seguir por onde o professor os conduz (PONTE, 2005, p.13).

${ }^{2}$ Traduzindo para o português utilizado no Brasil, podemos chamar de ensino direto. Segundo Ponte (2005), existem outras terminologias que caracterizam este estilo de ensino, como ensino expositivo, ensino magistral e ensino tradicional. 
O outro estilo de prática pedagógica, que segue em alternativa ao conceito do ensino direto, é o ensino-aprendizagem exploratório ${ }^{3}$. Segundo Ponte (2010) a caraterística principal é que o professor não tema intenção de explicar todo o conteúdo em questão, deixando parte deste esforço para o aluno, que descobre e constrói seu conhecimento. Desta forma, o professor assume um papel de mediador no processo de ensinoaprendizagem.

Conforme Azevedo et al. (2013) para a realização de tarefas de investigação, utiliza-se o modo coletivo quando o professor quer interagir com todos os alunos e estes interagirem entre si; o trabalho em grupo ou em pares quando deseja proporcionar um ambiente estimulante de partilha, onde os alunos podem participar coletivamente ou individualmente dentro do grupo formado; e o trabalho individual, quando pretende-se desenvolver a concentração e reflexão do aluno.

Em relação as suas estruturas, Christiansen e Walther ${ }^{4}$ (1986, apud Ponte, 2010) a divide em três segmentos principais:

i. $\quad$ apresentação da tarefa e a sua interpretação pelos alunos;

ii. desenvolvimento do trabalho pelos alunos;

iii. discussão e síntese final.

Na apresentação da tarefa, é realizada a negociação entre os alunos e professores da tarefa a realizar, na qual inclui a própria formulação da tarefa, sua interpretação, formas de trabalho a serem desenvolvidas. Em seguida, no que chamamos de desenvolvimento do trabalho, os alunos trabalham de forma autônoma, conforme o modo pré-determinado - em grupos, pares ou individualmente. Por último, apresenta-se os resultados dos trabalhos desenvolvidos, realizando então a discussão e a síntese final, que “[...] é a ocasião mais apropriada para que sejam expostas conexões e significados, permitindo aos alunos relacionar ideias sobre vários temas, mostrando como as ideias

\footnotetext{
${ }^{3}$ Outras terminologias utilizadas são ensino por descoberta e ensino ativo (PONTE, 2010).

${ }^{4}$ CHRISTIANSEN, B.; WALTHER, G. Task and activity. In B. Christiansen, A. G. Howson \& M. Otte (Eds.), Perspectives on mathematics education (pp. 243-307). Dordrecht: D. Reidel. 1986.
} 
matemáticas são naturalmente interligadas" (BISHOP E GOFFREE 5 , 1986, apud AZEVEDO et al. 2013, p.7).

\subsection{Diferenças entre ensino direto e investigação matemática}

A Matemática, baseada nos seus valores formativos e instrumental, apresenta diferentes tipos de tarefas no cotidiano escolar. Segundo Ponte (2003), as tarefas são classificadas em exercícios, problemas, exploração e investigação; além disso, cada tarefa possui quatro dimensões básicas: grau de dificuldade, estrutura, contexto referencial e o tempo requerido para sua resolução.

Figura 3 - Os diversos tipos de tarefas, em termos de dificuldade e estrutura.

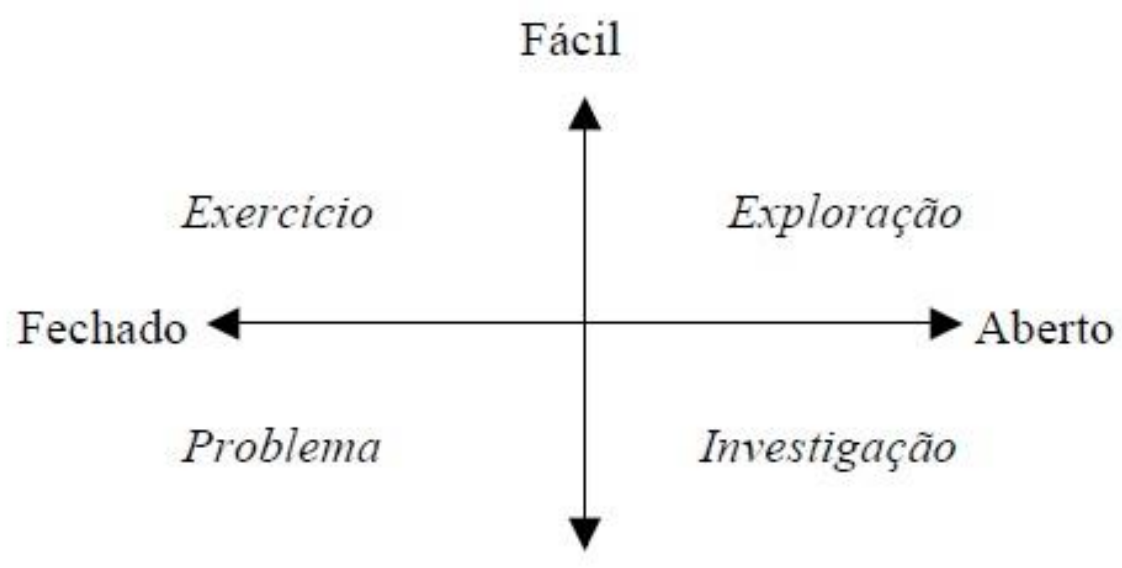

Difícil

Fonte: Ponte (2003)

${ }^{5}$ BISHOP, A.; GOFFREE, F. Classroom organization and dynamics. In: CHRISTIANSEN, B., HOWSON, A. G. \& OTTE, M. (Eds.), Perspectives on mathematics education (pp. 309-365). Dordrecht: D. Reidel, 1986, P. 309-365 
Os exercícios (2 quadrante) são tarefas sem grande dificuldade, com uma estrutura fechada e que tem como objetivo principal a consolidação de conhecimentos. Também com a estrutura fechada, os problemas (3 quadrante) possuem dificuldade elevada e visam a aplicação criativa de conhecimentos prévio. Do outro lado do eixo vertical, encontram-se as tarefas com estruturas abertas. As tarefas de exploração (1ำ quadrante) de desafio reduzido, com o intuito de construir novos conceitos e as tarefas de investigações (4ㅇ quadrante), que têm um grau de dificuldade elevado, visando tanto o desenvolvimento de novos conceitos quanto o uso criativo de conceitos já adquiridos.

- As tarefas de natureza mais fechada (exercícios, problemas) são importantes para o desenvolvimento do raciocínio matemático nos alunos, uma vez que este raciocínio se baseia numa relação estreita e rigorosa entre dados e resultados.

- As tarefas de natureza mais acessível (explorações, exercícios), pelo seu lado, possibilitam a todos os alunos um elevado grau de sucesso, contribuindo para o desenvolvimento da sua autoconfiança.

- As tarefas de natureza mais desafiante (investigações, problemas), pela sua parte, são indispensáveis para que os alunos tenham uma efectiva experiência matemática.

- As tarefas de cunho mais aberto são essenciais para o desenvolvimento de certas capacidades nos alunos, como a autonomia, a capacidade de lidar com situações complexas, etc.

(PONTE, 2005, p.17)

Vale ressaltar que as tarefas de exploração e de investigação muitas vezes são classificadas por somente investigações, provavelmente devido ao fato de ser "[...] complicado saber, à partida, qual o grau de dificuldade que uma tarefa aberta terá para um certo grupo de alunos" (PONTE, 2003, p.5).

Em relação a dimensão tempo, as tarefas podem ser de curta, média ou longa duração. Geralmente os exercícios, tarefas fechadas enquadram-se nas tarefas de curta duração. Já em relação as tarefas de cunho aberto, a diferença entre as tarefas de investigação e projeto é meramente em relação ao tempo. Desta forma, "Um projecto, no 
fundo, não é mais do que uma tarefa de investigação de um tipo particular, com um carácter relativamente prolongado. De facto, uma investigação chama-se muitas vezes "projecto de investigação" e pode demorar anos a concluir" (PONTE, 2010, p.22).

Figura 4 - Eixo correspondente dos diferentes tipos de tarefas, quanto ao tempo.

\begin{tabular}{lcr} 
Curta & Média & Longa \\
\hline Exercícios & $\begin{array}{c}\text { Problemas } \\
\text { Tarefas de exploração }\end{array}$ & Projectos
\end{tabular}

Tarefas de investigação

Fonte: PONTE (2005).

Vale ressaltar ainda que, dependendo do objetivo a alcançar "[...] certas investigações demoram um tempo relativamente curto, podendo realizar-se numa aula ou numa curta sequência de aulas" (PONTE, 2010, p.22).

A dimensão do contexto referencial tem sua relevância quando estamos trabalhando algum tipo de tarefa em sala de aula. Elas podem assumir um caráter contextualizado, com a aplicação de alguma situação real; contextualizado com caráter semirreal, nas quais possuem relações com a realidade, mas que no fundo são abstratas (SKVOMOSE 6 , 2000 apud PONTE, 2003); e as internas da própria matemática.

Figura 5 - Eixo correspondente dos diferentes tipos de tarefas, quanto ao contexto.

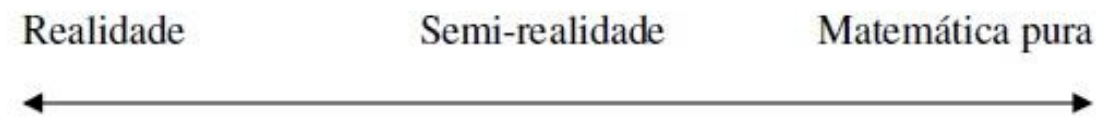

Fonte: PONTE (2005)

${ }^{6}$ SKOVSMOSE, O. Cenários para investigação. Bolema, 14, 66-91. 2000. 
Em resumo, as duas práticas pedagógicas apontadas por PONTE apresentam características próprias em relação à tarefa, aos papéis dos alunos e professores e da comunicação em sala de aula, destacadas na tabela abaixo:

Tabela 1 - Principais características entre Ensino direto e Ensino-aprendizagem exploratória

\begin{tabular}{|c|c|}
\hline Ensino direto & Aprendizagem exploratória \\
\hline $\begin{array}{cl}\text { Tarefas } & \\
\text { - } & \text { Tarefa padrão: Exercício; } \\
\text { - } & \text { As situações são artificiais; } \\
\text { - } & \text { Para cada problema existe uma } \\
& \text { estratégia e uma resposta certa. }\end{array}$ & $\begin{array}{l}\text { Tarefas } \\
\text { - Variedade: Explorações, Investigações, } \\
\text { - Problemas, Projetos, Exercícios; } \\
\text { - As situações são realísticas; } \\
\text { - Com frequência, existem várias } \\
\text { estratégias para lidar com um problema. }\end{array}$ \\
\hline 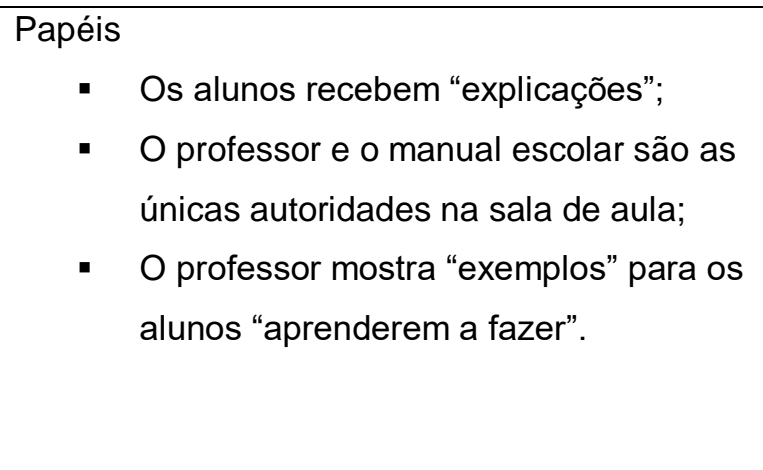 & $\begin{array}{l}\text { Papéis } \\
\text { - Os alunos recebem tarefas para } \\
\text { descobrirem estratégias para as } \\
\text { resolver; } \\
\text { - O professor pede ao aluno para explicar } \\
\text { e justificar o seu raciocínio; } \\
\text { - O aluno é autoridade se usar raciocínio } \\
\text { lógico para fundamentar as afirmações. }\end{array}$ \\
\hline $\begin{array}{l}\text { Comunicação } \\
\text { - O professor coloca questões e fornece } \\
\text { feedback imediato (sequência l-R-F); } \\
\text { - O aluno coloca "dúvidas". }\end{array}$ & $\begin{array}{l}\text { Comunicação } \\
\text { - Os alunos são encorajados a discutir } \\
\text { com os colegas (trabalhando em grupos } \\
\text { ou pares); } \\
\text { - No fim de um trabalho significativo, } \\
\text { fazem-se discussões com toda a turma; } \\
\text { - Significados negociados na sala de } \\
\text { aula. }\end{array}$ \\
\hline
\end{tabular}

Fonte: Ponte (2010).

\footnotetext{
${ }^{7}$ Em muitas aulas de Matemática, o professor domina o discurso, seja fornecendo explicações e exemplos ou colocando questões e dando um retorno imediato aos alunos. Essas aulas tendem a seguir a sequência IRF - o professor Inicia com uma pergunta, um aluno responde e o professor fornece Feedback, fechando o ciclo, quer confirmando ou rejeitando a resposta dada (PONTE, 2010, p.23).
} 
De um modo geral, a teoria apresentada por Ponte que relaciona o ensino direto e o ensino investigativo, nos aponta que as práticas de ensino de caráter investigativo, contribuem de forma mais eficaz para que se alcance os objetivos propostos em relação a formação integral do aluno do ensino médio pois tem a pesquisa como fundamento pedagógico e o trabalho como princípio educativo.

Como vimos anteriormente, as investigações na área de matemática podem ser desenvolvidas em uma aplicação da realidade ou semi-realidade ou em contextos puramente matemáticos. Entretanto, de acordo com as dificuldades apontadas pelas pesquisas do ensino superior que apontam um certo nível de fragilidade no conhecimento matemático dos alunos provindos do ensino médio e com intuito de aproximar os alunos da escola básica à matemática superior, a intenção deste trabalho é relacionar tarefas de cunho investigativo internas da matemática com foco em trabalhar a demonstração em sala de aula.

Fato é que o tema demonstração é particular a comunidade dos profissionais da área de matemática, entretanto ela pode assumir um papel colaborativo na formação do aluno do ensino médio, tanto no desenvolvimento da capacidade matemática, quanto no desenvolvimento intelectual como um todo. Para tanto, voltaremos nossos olhos à teoria de Balacheff que define as principais diferenças entre uma demonstração, uma prova e uma explicação, além de tratar do assunto de argumentação, que apesar de não ser formal para realizar uma demonstração, contribui muito para o desenvolvimento do pensamento matemático para os alunos do ensino médio e superior.

Para isso, faremos um estudo sobre como podemos tratar desse assunto no ensino médio de tal forma que, agregado a tarefas de investigação, procure despertar no aluno o interesse de estudar matemática. 


\section{Capítulo 3}

\section{A demonstração matemática no Ensino Médio}

\subsection{O pensamento demonstrativo e a história da matemática}

Desde pequenos aprendemos na escola a história do pastor de ovelhas que utilizava pedras para contar a quantidade de ovelhas em seu rebanho. Daí, teria surgido a matemática. Esse relato simplista representa a associação entre matemática e atividades práticas cotidianas. Obras de História da Matemática mostram que ela teria surgido devido a necessidade humana de realizar operações básicas necessárias para a sua subsistência. De acordo com O'Connor e Robertson (2017) cerca de 30.000 anos antes da era cristã (AEC) os povos paleolíticos - localizados na Europa central e França - teriam já gravado marcas em ossos que representariam contagens. Entretanto, é comum essas obras tomarem como ponto de partida da história da matemática relacionando ao surgimento da escrita, que data aproximadamente 3200 AEC.

A Mesopotâmia - região localizada entre os rios Tigres e Eufrates - e o Egito Antigo - região próxima ao Rio Nilo - são as duas civilizações mais antigas que possuem registros escritos. As gravações em tabletes de argila feitas através de escritas cuneiformes criadas pelos sumérios aperfeiçoadas pelos babilônios - e as folhas de papiro - criadas pelos egípcios - permitiram através de estudos, definir como era praticada a matemática da época.

As fontes indicam que quando a matemática começou a ser praticada no antigo Egito, ela estava associada sobretudo a necessidades administrativas. A quantificação e o registro de bens levaram ao desenvolvimento de sistemas de medida, empregados e aperfeiçoados pelos escribas, ou seja, pelos responsáveis 
pela administração do Egito. Esses profissionais eram importantes para assegurar a coleta e a distribuição dos insumos, mas também para garantir a formação de novos escribas. Os papiros matemáticos se inserem nessa tradição pedagógica e contêm problemas e soluções preparados por eles para antecipar as situações que os mais jovens poderiam encontrar no futuro (ROQUE, 2012, p.38).

Segundo Eves (2011), com o intuito de tornar essas regiões agricultáveis ricas, a drenagem de pântanos, controle de inundações e a irrigação implicaram no desenvolvimento considerável da tecnologia existente, bem como o conhecimento matemático da época. Devido a necessidade prática, afirma-se que os conhecimentos matemáticos dos mesopotâmios e egípcios eram baseados em procedimentos - ou algoritmos - para a resolução de problemas pertinentes a um determinado contexto, não questionando se um procedimento específico poderia ser estendido para casos gerais.

[...] nenhum exemplo do que hoje chamamos demonstração pode ser encontrado na matemática oriental antiga. Em vez de um argumento encontra-se meramente a descrição de um processo. Instrui-se: “Faça assim e assim” (EVES, 2011, p.58).

Devido a mudanças econômicas e políticas, algumas civilizações desapareceram ao longo dos dois últimos milênios antes da era comum. O declínio dos egípcios e dos babilônios - civilização que, por volta de 1900 AEC, tinha dominado boa parte da região da mesopotâmia - fez com que outros povos, entre os quais, os gregos, assumissem um papel de destaque na história. Desta forma iniciava-se um novo período na história - A Antiguidade Clássica (EVES, 2011).

Tradicionalmente, alguns estudos da história da matemática apontam a origem do conhecimento matemático grego proveniente dos Egípcios e Babilônios. Sabe-se que os primeiros matemáticos gregos praticavam uma matemática parecida com a dos mesopotâmicos e egípcios. Entretanto, Roque (2012) afirma que, apesar de existir uma influência entre os mesopotâmios e gregos, não se pode afirmar exatamente como aconteceu este intercâmbio. 
Não há, contudo, uma documentação confiável que possa estabelecer a transição da matemática mesopotâmica e egípcia para a grega. Essa é, na verdade, uma etapa na construção do mito de que existiria uma matemática geral da humanidade. A escassez de fontes que permitiriam unir as diferentes práticas dessas disciplinas na Antiguidade nos força a optar pela presença de várias manifestações matemáticas (ROQUE, 2012, p.94).

Durante os anos 600 e 500 AEC, o crescimento populacional e a dispersão dos gregos ao longo do Mediterrâneo deram origem a um modelo de cidades gregas denominadas polis ${ }^{8}$. Com o intuito de discutir sua organização política, administrativa religiosa e militar, fez desta época com que surgissem os debates, no qual discursos que tinham intuito de convencer o próximo - um dos objetivos da argumentação, no contexto deste trabalho - ganhassem força dentro da cultura Grega.

\footnotetext{
A polis surgiu ao mesmo tempo em que o cidadão passou a ter direito de reger sua cidade. Para isso, eram necessários parâmetros, o que alimentava o gosto pela discussão. A controvérsia movimentava a polis e a capacidade de persuasão, que contribuía para vencer o debate, tornou-se valorizada (ROQUE, 2012, p.95).
}

Nesta época, o processo de formação educativa de um indivíduo da sociedade grega era constituído por sete artes liberais - ou sete ramos do conhecimento - divididas em dois grupos: O Trivium e o Quadrivium.

Segundo Joseph (2002) Trivium significa o cruzamento e a articulação de três ramos ou caminhos. Abrangia os aspectos relacionados à mente e, conforme definição, era constituído por três das sete artes liberais: a Lógica - a arte de pensar; a Gramática - a arte dos símbolos para a expressão do pensamento; e a Retórica - a arte de persuasão nos mais diversos assuntos da época.

Em complemento, o Quadrivium - cruzamento e articulação de quatro ramos ou caminhos - abrangia os aspectos relacionados à matéria e era composto pelas quatros

\footnotetext{
${ }^{8}$ Segundo Roque (2012), a palavra polis está relacionada à política, no sentido de que concerne ao cidadão, aos negócios públicos.
} 
artes liberais restantes: a Aritmética - teoria dos números; a Música - aplicação da teoria dos números na medição de quantidades discretas em movimento, como por exemplo o estudo estrutural da escala harmônica; A Geometria - teoria do espaço; e a Astronomia aplicação da teoria do espaço.

Assim era eminente que o poder de persuasão, aliado ao espírito crítico características do povo grego - levassem a questionamentos sobre a validade dos conhecimentos matemáticos da época.

Pela primeira vez na matemática, como em outros campos, o homem começou a formular questões fundamentais como "Por que os ângulos da base de um triangulo isósceles são iguais? " e "Porque o diâmetro de um círculo divide esse círculo ao meio?" (EVES, 2011, p.94).

Roque (2012) remete aos eleatas ${ }^{9}$, como Parmênides (séc. V AEC), as primeiras tentativas de introduzir uma argumentação lógica, na qual os pensamentos progridem sistematicamente de um a outro. Entretanto, na obra Os Elementos - de Euclides (por volta de $300 \mathrm{AEC}$ ), a matemática na Grécia parece ter adquirido uma configuração particular - com característica de uma organização formal, axiomática - passando a empregar enunciados geométricos gerais, que não envolviam somente procedimentos de medida. As demonstrações contidas nesta obra refletem a cultura da época - baseada na argumentação para convencer - e dá origem a caracterização da matemática com sendo uma ciência única.

Dentre as técnicas de persuasão, as regras da demonstração e o apelo a uma lógica que busca o verdadeiro, própria do saber teórico, passaram a ter especial destaque, e quem soubesse persuadir sempre poderia convencer os outros de que sua tese era verdadeira (ROQUE, 2012, p.95-96).

${ }^{9}$ Membros da Escola Eleática, situada na cidade Eleia. Além de Parmênides, outros três filósofos fizeram parte da Escola Eleática: Xenófanes, Zenão e Melisso. 
Além do fato de que os matemáticos gregos tiveram que lidar com problemas de caráter abstratos e complexos, que não eram possíveis de serem realizados por meio de cálculos - como por exemplo a incomensurabilidade - a sistematização e organização do pensamento matemático da obra de Euclides, pode ser dada pelo fato de facilitar a transmissão do conhecimento nas escolas.

\footnotetext{
A organização em escolas, cujo objetivo era transmitir o conhecimento matemático da época, pode ter gerado uma demanda pela compilação e sistematização desse conhecimento. A necessidade de colocar em ordem a aritmética e a geometria herdadas das tradições mais antigas, bem como as descobertas recentes, deve ter levado, naturalmente, a um questionamento sobre a forma de expor o conteúdo matemático (ROQUE, 2012, p.108).
}

Independentemente da razão de sua produção, fato é que o método de sistematização e organização da obra Os Elementos, baseado em postulados, proposições e demonstrações, continua relevante até os dias atuais. Courant e Robbins (2000, p.262) afirmam que "[...] a impressão causada por esta obra foi tão grande sobre as gerações subsequentes, que se tornou um modelo para todas as demonstrações rigorosas em matemática". Em particular, na matemática moderna, o método axiomático é usado como estrutura formal em muitas áreas, sendo essencial para a sua constante evolução e, em consequência, contribuindo para a evolução das demais ciências que apoiam na matemática. 


\subsection{Argumentação e Demonstração}

Como veremos nos capítulos a seguir uma das finalidades do ensino médio é desenvolver no indivíduo, sua autonomia intelectual e pensamento crítico. Estar apto a desenvolver opiniões sobre os diversos questionamentos do mundo com argumentos concisos é considerado essencial para que o indivíduo possa exercer o papel da cidadania. Uma das formas de desenvolver esta capacidade, segundo os documentos oficiais, é estimular o aluno, desde os anos iniciais do ensino fundamental, a conjecturar e tomar decisões sobre a validade de um fato matemático, exibindo contraexemplos, no caso de refutação, ou utilizando o raciocínio lógico, no caso de uma validação. Desta forma argumentar e demonstrar na área de matemática são competências pertinentes no contexto da escola básica.

Argumentação e demonstração são palavras comuns no âmbito da Matemática. Entretanto, essas palavras, assumem diferentes significados que, para um melhor entendimento em relação a distinção destas duas palavras-chave, faz jus apoiarmos em referenciais teóricos, que servirão de base para o desenvolvimento deste trabalho.

Começamos então a tratar especificamente sobre a demonstração. Segundo Almouloud et al. (2008, p.218) "usualmente, consideramos a demonstração como um procedimento de validação que caracteriza a matemática e a distingue das ciências experimentais, além de ocupar um lugar de destaque nessa disciplina". Assim como a demonstração, frequentemente a palavra prova aparece em diversas literaturas e ambas parecem ter um mesmo significado. Para realizar tal distinção, Balacheff ${ }^{10}$ (1988 apud D'AMORE, 2007, p.345-346), define alguns termos pertinentes a esta área de pesquisa. Desta forma, teremos intuito de melhor entender o que vem a ser uma demonstração matemática.

\footnotetext{
${ }^{10}$ BALACHEFF, N. Une étude des processus de preuve en mathématiques chez des élèves de Collège. Thése d'État, Univ. J. Fourier, Grenoble. 1988.
} 
explicação é um ato (ou, melhor, um processo) concebido por si mesmo, com meios próprios e pessoais, com base em competências pessoais, mas já dirigido a uma explicação futura destinada a outros; trata-se, de outro modo, de um fato pessoal, interno. (BALACHEFF ${ }^{10}, 1988$ apud D'AMORE, 2007, p.345)

O termo explicação definido por Balacheff aparece geralmente no contexto de sala de aula quando é adotada uma postura, por parte do professor, de detentor do conhecimento. Podemos utilizar como exemplo quando ensinamos as propriedades de logaritmos a nível de ensino médio, onde caracteriza-se uma explicação o ato da simples comunicação que $\log _{b}(a \cdot c)=\log _{b} a+\log _{b} c$. Desde que a explicação seja convincente para uma certa comunidade, a propriedade é admitida como verdadeira. Para isso, cabe ao professor (locutor) traçar diferentes estratégias para comunicar ao aluno (receptor) a validade desta propriedade, seja em nossa língua materna (a soma de logaritmos de mesma base é igual ao logaritmo do produto dos logaritmando), seja com exemplos de casos particulares, como segue abaixo:

$$
\log _{2}(64)=\log _{2}(4 \cdot 16)
$$

Adotando $a=4$ e $c=16$ temos, pela propriedade $\log _{b}(a \cdot c)=\log _{b} a+$ $\log _{b} c$, que:

$$
\log _{2}(64)=\log _{2} 4+\log _{2} 16=2+4=6
$$

O que valida - ou leva a ser aceita pelo receptor - a propriedade $\log _{b} a+$ $\log _{b} c=\log _{b}(a \cdot c)$. 
prova é a fase sucessiva, socialmente compartilhada, ainda não definitiva, mas em evolução; as provas podem ser pragmáticas ou intelectuais, cada uma das duas categorias possui características e linguagens próprias (ainda que com interações notáveis); os alunos parecem passar das provas pragmáticas para as intelectuais em quatro passagens:

- comportamento empirista e ingênuo: o estudante extrai validade geral do tratamento de alguns casos;

- pesquisa do experimento crucial, para poder escolher entre várias situações possíveis e descartar algumas não convenientes;

- generalização do exemplo;

- experimento mental;

(BALACHEFF ${ }^{10}, 1988$ apud D'AMORE, 2007, p.345)

Desta forma, podemos entender por provas pragmáticas as que utilizam como base os conhecimentos práticos, como cálculos diretos de verificação, manipulação de materiais concretos, recortes e dobraduras de figuras, construção de gráficos e desenhos. Já as provas intelectuais, são baseadas em argumentos que implicam propriedades e suas relações através da linguagem matemática.

As provas pragmáticas são aquelas que recorrem a uma ação atual ou showing, e, pelo contrário, as provas conceituais são aquelas que não envolvem ações e resultam de formulações de propriedades em questões e relações entre elas.

(BALACHEFF ${ }^{11}$,1987, p. 217 apud AMOULOUD, 2008, p. 266)

Decorrentes do Teorema de Tales, as razões trigonométricas seno e cosseno, apresentadas na última etapa do Ensino Fundamental II, são aprofundadas no Ensino Médio quando introduzimos o conceito de ciclo trigonométrico, que serve de base para o estudo dos comportamentos de funções trigonométricas. Nesta etapa é apresentada aos alunos a conhecida Relação Fundamental da Trigonometria $\operatorname{sen}^{2} x+\cos ^{2} x=1$.

\footnotetext{
${ }^{11}$ BALACHEFF, N. Processus de preuve et situations de validation. Educational Studies in Mathematics, v.18, n.2, 1987, pp.147-176.
} 
O conceito de prova proposto por Balacheff pode ser identificado em atividades que questionem a validade desta relação e coloque o aluno em uma situação que proporcione a elaboração de uma prova matemática. Desta forma, tomemos como exemplo uma atividade onde deve-se provar que $\operatorname{sen}^{2} x+\cos ^{2} x=1$.

As quatro etapas que constituem a passagem de prova pragmática para intelectual podem ser identificadas conforme proposta da aula e postura do aluno mediante ao desafio proposto. Desta forma, o comportamento empirista - primeira etapa de generalização - fica evidente quando o aluno verifica a relação fundamental da trigonometria para alguns ângulos notáveis do 1 ㅇquadrante - no caso $\frac{\pi}{6}, \frac{\pi}{4} \mathrm{e} \frac{\pi}{3}$ - através de alguns cálculos conforme exemplos abaixo:

$$
\begin{aligned}
& \operatorname{sen}^{2}\left(\frac{\pi}{6}\right)+\cos ^{2}\left(\frac{\pi}{6}\right)=\left(\frac{1}{2}\right)^{2}+\left(\frac{\sqrt{3}}{2}\right)^{2}=\frac{1}{4}+\frac{3}{4}=\frac{4}{4}=1 \\
& \operatorname{sen}^{2}\left(\frac{\pi}{4}\right)+\cos ^{2}\left(\frac{\pi}{4}\right)=\left(\frac{\sqrt{2}}{2}\right)^{2}+\left(\frac{\sqrt{2}}{2}\right)^{2}=\frac{2}{4}+\frac{2}{4}=\frac{4}{4}=1 \\
& \operatorname{sen}^{2}\left(\frac{\pi}{3}\right)+\cos ^{2}\left(\frac{\pi}{3}\right)=\left(\frac{\sqrt{3}}{2}\right)^{2}+\left(\frac{1}{2}\right)^{2}=\frac{3}{4}+\frac{1}{4}=\frac{4}{4}=1
\end{aligned}
$$

Em um segundo momento, quando questionado ou impulsionado pela descoberta, o aluno verifica se a relação fundamental da trigonometria vale para medidas angulares cujas imagens pertençam aos demais quadrantes - como por exemplo $\frac{2 \pi}{3}$ (2은 quadrante), $\frac{7 \pi}{6}$ ( 3 o quadrante) ou $\frac{7 \pi}{4}$ ( 4 o quadrante) - ou ainda, pertençam a um dos eixos do plano cartesiano $u v$ - como por exemplo $0, \frac{\pi}{2}, \pi, \frac{3 \pi}{2}$ e $2 \pi$ - colocamos o aluno frente a pesquisa do experimento crucial, onde ele verifica que a relação vale para medidas angulares diversas. 


$$
\begin{gathered}
\operatorname{sen}^{2}\left(\frac{7 \pi}{4}\right)+\cos ^{2}\left(\frac{7 \pi}{4}\right)=\left(-\frac{\sqrt{2}}{2}\right)^{2}+\left(\frac{\sqrt{2}}{2}\right)^{2}=\frac{2}{4}+\frac{2}{4}=\frac{4}{4}=1 \\
\operatorname{sen}^{2}(\pi)+\cos ^{2}(\pi)=(0)^{2}+(-1)^{2}=0+1=1
\end{gathered}
$$

Ainda como parte do experimento crucial, cabe a verificação da relação fundamental da trigonometria para medidas angulares negativas e maiores que $2 \pi$. De onde espera-se que the seja familiar a relação $\operatorname{sen}(x+2 \pi k)=\operatorname{sen}(x)$ e $\cos (x+2 \pi k)=$ $\cos (x)$ para algum $k \in \mathbb{Z}$.

$$
\begin{gathered}
\operatorname{sen}^{2}\left(\frac{15 \pi}{6}\right)+\cos ^{2}\left(\frac{15 \pi}{6}\right)=\operatorname{sen}^{2}\left(\frac{3 \pi}{6}+\frac{12 \pi}{6}\right)+\cos ^{2}\left(\frac{3 \pi}{6}+\frac{12 \pi}{6}\right) \\
=\operatorname{sen}^{2}\left(\frac{\pi}{3}+2 \pi\right)+\cos ^{2}\left(\frac{\pi}{3}+2 \pi\right)=\operatorname{sen}^{2}\left(\frac{\pi}{3}\right)+\cos ^{2}\left(\frac{\pi}{3}\right)=\left(\frac{\sqrt{3}}{2}\right)^{2}+\left(\frac{1}{2}\right)^{2}=1
\end{gathered}
$$

A utilização de diferentes tipos de representações, bem como suas interações, é importante nos estudos de trigonometria. Através da representação gráfica da circunferência trigonométrica e a imagem de um comprimento $x$, localizada no primeiro quadrante, a terceira etapa proposta por Balacheff - generalização de um exemplo - pode ser evidenciada quando se generaliza que $\operatorname{sen}^{2} x+\cos ^{2} x=1$.

Figura 6 - Representação gráfica da circunferência trigonométrica.

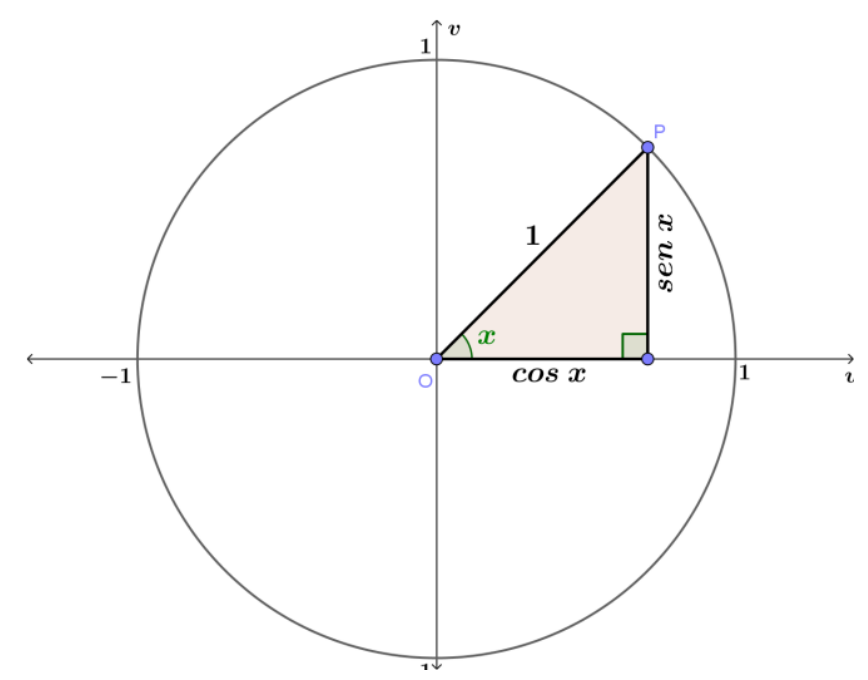

Fonte: Próprio Autor. 
A validade deste fato baseia-se no Teorema de Pitágoras, onde é visualizado que o triângulo formado, no primeiro quadrante, tem como medidas dos catetos senx e $\cos x$ e a hipotenusa igual a 1 . Mesmo que haja a extensão do conceito para medidas angulares dos demais quadrantes, a generalização poderá ser realizada, desde que haja a percepção de que sempre será possível construir, devido ao raio da circunferência trigonométrica, um triângulo retângulo cuja medida da hipotenusa seja igual a 1 e as medidas dos catetos $|\operatorname{sen} x|$ e $|\cos x|$.

Figura 7 - Representação gráfica da imagem P nos demais quadrantes.
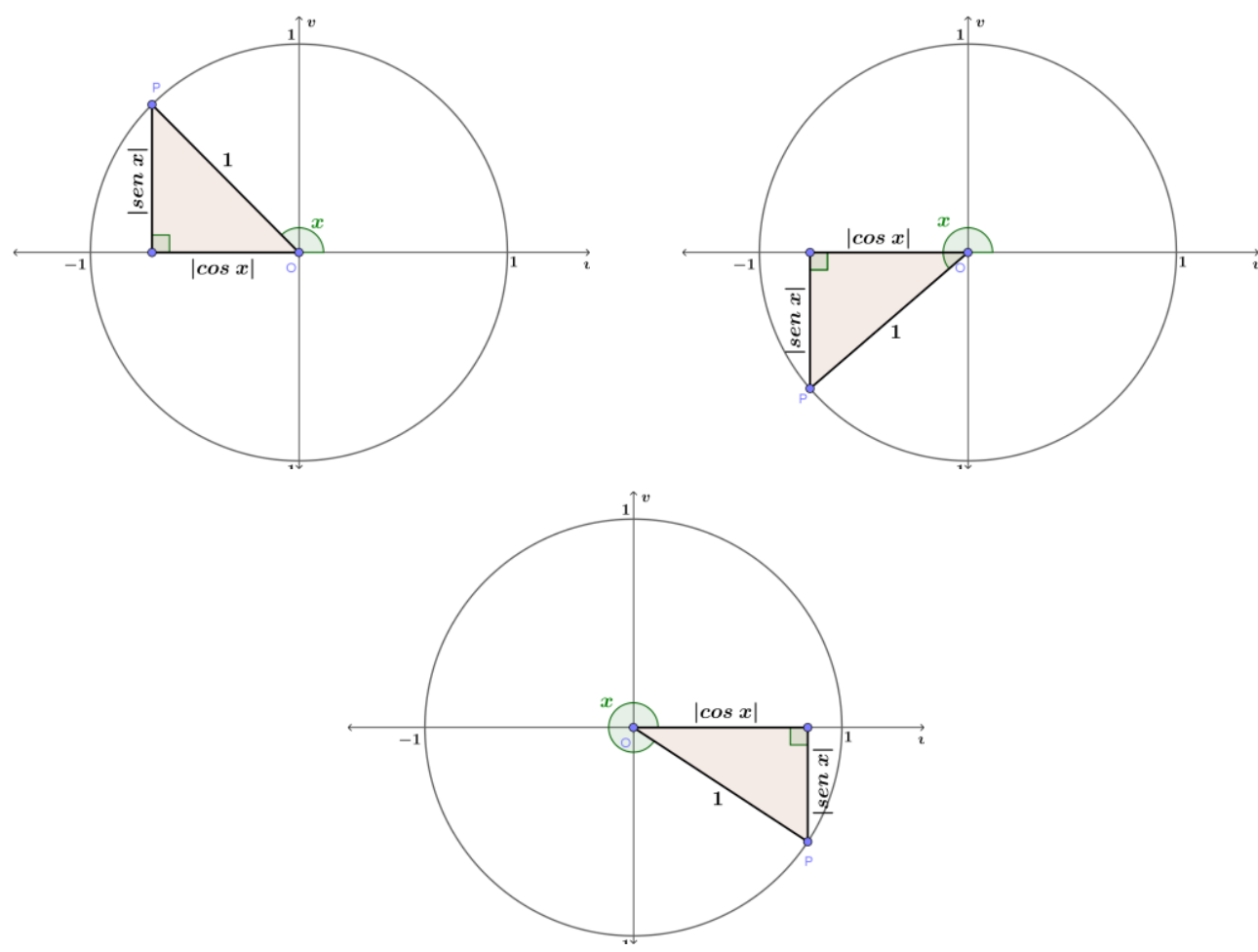

Fonte: Próprio Autor.

Esta generalização é feita para uma determinada classe de objetos, que no caso são os triângulos retângulos cuja hipotenusa mede 1, devido a circunferência trigonométrica. Entretanto é pertinente o questionamento se esta relação vale para um triângulo retângulo qualquer, ou seja, provar que se $A B C$ é um triângulo retângulo, então $\operatorname{sen}^{2} x+\cos ^{2} x=1$ é verdade. Neste momento é esperado que se realize a última etapa que constitui o conceito de prova de Balacheff - o experimento mental. Com base na álgebra e na geometria, caracteriza-se uma prova intelectual um raciocínio com o seguinte desenvolvimento: 
Seja $A B C$ um triângulo retângulo em $B$. De acordo com as razões trigonométricas, temos por definição que:

$$
\begin{gathered}
\text { senx }=\frac{\text { cateto oposto }}{\text { hipotenusa }}=\frac{\operatorname{med}(\overline{B C})}{\operatorname{med}(\overline{A C})} \\
\cos x=\frac{\text { cateto adjacente }}{\text { hipotenusa }}=\frac{\operatorname{med}(\overline{A B})}{\operatorname{med}(\overline{A C})}
\end{gathered}
$$

Desta forma, segue que:

$$
\operatorname{sen}^{2} x+\cos ^{2} x=\left(\frac{\operatorname{med}(\overline{B C})}{\operatorname{med}(\overline{A C})}\right)^{2}+\left(\frac{\operatorname{med}(\overline{A B})}{\operatorname{med}(\overline{A C})}\right)^{2}=\frac{(\operatorname{med}(\overline{B C}))^{2}+(\operatorname{med}(\overline{A B}))^{2}}{(\operatorname{med}(\overline{A C}))^{2}}
$$

Pelo Teorema de Pitágoras, temos que $(\operatorname{med}(\overline{B C}))^{2}+(\operatorname{med}(\overline{A B}))^{2}=$ $(\operatorname{med}(\overline{A C}))^{2}$, de onde segue que:

$$
\operatorname{sen}^{2} x+\cos ^{2} x=\frac{(\operatorname{med}(\overline{B C}))^{2}+(\operatorname{med}(\overline{A B}))^{2}}{(\operatorname{med}(\overline{A C}))^{2}}=\frac{(\operatorname{med}(\overline{A C}))^{2}}{(\operatorname{med}(\overline{A C}))^{2}}=1
$$

É possível notar que o raciocínio ${ }^{12}$ de um experimento crucial possui uma linguagem própria, com características próximas da matemática formal. Reforçando as ideias de Balacheff, Almouloud (2008) descreve que as provas são explicações aceitas por outros num determinado momento, podendo ter o estatuto de prova para determinado grupo social, mas não para um outro.

Já as demonstrações são provas particulares, que respeitam certas regras que constituem a teoria axiomática, trabalhando objetos matemáticos com um estatuto teórico, sendo assim as únicas aceitas pelos matemáticos.

\footnotetext{
${ }^{12}$ Segundo Balacheff ${ }^{3}$ (1988 apud D'AMORE, 2007, p.346), "raciocínio é uma atividade por meio da qual se produzem informações novas a partir de outras já conhecidas; trata-se de algo interno, pessoa, não necessariamente compartilhado por outros."
} 
demonstração nela respeitam-se regras dedutivas estabelecidas, notáveis e compartilhadas (ou impostas); é óbvio que quem propõe uma demonstração assume um papel particular, procura uma linguagem idônea; isso obriga, portanto, quem propõe a demonstração a passar da língua comum para aquela formal; segundo Balacheff isso acontece em 3 fases:

- a descontextualização que permite o distanciamento do particular caso considerado;

- a despersonalização que permite fazer com que o resultado não dependa de quem o está produzindo;

- a destemporalização;

(BALACHEFF', 1988 apud D'AMORE, 2007, p.345)

Para ilustrar o conceito de demonstração proposto por Balacheff, Lima (2014) faz uma lista com fatos elementares sobre os números reais $\mathbb{R}$, nos quais os chama de axiomas. Estes fatos são assumidos como verdade - ou seja, não são demonstrados - e, a partir deles, todos os demais resultados contidos no decorrer de sua teoria são deduzidos. Desta forma, $\mathbb{R}$ é apresentado como um corpo ordenado completo.

Um corpo é um conjunto $K$, munido de duas operações, chamadas de adição e multiplicação, que satisfazem certas condições chamados de axiomas de corpo, abaixo especificadas. A adição faz corresponder a cada par de elementos $x, y \in K$ sua soma $x+y \in K$, enquanto que a multiplicação associa a esses elementos o seu produto $x \cdot y \in K$. Os axiomas de corpo são os seguintes:

A. Axiomas da adição

A1. Associatividade - quaisquer que sejam $x, y, z \in K$, tem-se $(x+y)+z=x+$ $(y+z)$.

A2. Comutatividade - quaisquer que sejam $x, y \in K$, tem-se $x+y=y+x$

A3. Elemento Neutro - a existe $0 \in K$ tal que $x+0=x$, seja qual for $x \in K$. 0 Elemento 0 chama-se zero.

A4. Simétrico - todo elemento $x \in K$ possui um simétrico $-x \in K$ tal que $x+$ $(-x)=0$ 
M. Axiomas da multiplicação

M1. Associatividade - dados quaisquer $x, y, z \in K$, tem-se $(x \cdot y) \cdot z=x \cdot(y \cdot z)$

M2. Comutatividade - sejam quais forem $x, y \in K$, vale $x \cdot y=y \cdot x$

M3. Elemento neutro - existe $1 \in K$ tal que $1 \neq 0$ e $x \cdot 1=x$, qualquer que seja $x \in K$. O elemento 1 chama-se "um".

M4 - Inverso Multiplicativo - todo $x \neq 0$ em $K$ possui um inverso $x^{-1}$, tal que $x$. $x^{-1}=1$.

D1. Axioma da distributividade. Dados $x, y, z$ quaisquer, em $\mathrm{K}$, tem-se $x \cdot(y+z)=$ $x \cdot y+x \cdot z$.

(LIMA, 2014, p.61-63)

Um dos primeiros mistérios da matemática da escola básica, apresentado nos anos iniciais do ensino fundamental II, é a chamada regra dos sinais. O desafio didático em torno deste assunto fez com que surgissem diversas estratégias para sua abordagem. Entretanto, erros em relação ao sinal de uma multiplicação de dois números inteiros são frequentes e se estendem aos números reais, fazendo parte do cotidiano do aluno até o final do ensino médio. Isto pode nos levar a entender que, por mais que haja um grande esforço por partes dos professores em ensinar a regra dos sinais, a assimilação por parte dos alunos deste fato é meramente mecânica.

Baseado no método axiomático proposto por Lima, conseguimos demonstrar a regra dos sinais. Para isso, assumimos o conceito de igualdade (indicado pelo símbolo =) como uma relação de equivalência. Desta forma, para todo $x, y, z \in K$ valem as propriedades reflexiva $(x=x)$, simétrica $(x=y \Rightarrow y=x)$ e $\operatorname{transitiva}((x=y \wedge y=z)$ $\Rightarrow x=z)$. Também é válido somar algum elemento $y \in K$ em ambos os lados de uma igualdade. Primeiramente vamos demonstrar que qualquer elemento de um corpo multiplicado pelo elemento neutro da adição é igual ao próprio elemento neutro. 
(Teorema 1). Seja $x \in K$. Então $x \cdot 0=0$

\section{Demonstração:}

$$
\begin{array}{ll}
x \cdot 0+x \cdot 0=x \cdot(0+0) & \text { (D1) } \\
x \cdot(0+0)=x \cdot 0 & \text { (A3) } \\
x \cdot 0+x \cdot 0=x \cdot 0 & \text { (Transitividade igualdade) } \\
(x \cdot 0+x \cdot 0)+(-x \cdot 0)=x \cdot 0+(-x \cdot 0) & \text { (Somando }-x \cdot 0 \quad \mathrm{em}
\end{array}
$$

ambos os membros)

$$
\begin{aligned}
& x \cdot 0+(x \cdot 0+(-x \cdot 0))=x \cdot 0+(-x \cdot 0) \\
& x+0=0
\end{aligned}
$$

Demonstrado o Teorema 1, vamos demonstrar a regra dos sinais de uma multiplicação.

(Regra dos Sinais). Sejam $x, y \in K$. Então $(-x) \cdot y=-(x \cdot y)$.

\section{Demonstração:}

$$
\begin{array}{ll}
(-x) \cdot y+x \cdot y=(-x+x) \cdot y & \text { (D1) } \\
(-x+x) \cdot y=0 \cdot y & \text { (A4) } \\
0 \cdot y=0 & \text { (Teorema 1) } \\
(-x) \cdot y+x \cdot y=0 & \text { (Transitividade igualdade) } \\
((-x) \cdot y+x \cdot y)+(-(x \cdot y))=0+(-(x \cdot y)) & \text { (Somando }-(x \cdot y) \mathrm{em}
\end{array}
$$

ambos os membros)

$$
\begin{aligned}
& (-x) \cdot y+(x \cdot y+(-(x \cdot y)))=0+(-(x \cdot y)) \\
& (-x) \cdot y+0=0+(-(x \cdot y)) \\
& (-x) \cdot y+0=(-(x \cdot y))+0 \\
& (-x) \cdot y=-(x \cdot y)
\end{aligned}
$$


De um modo geral, a argumentação é essencial em diversas áreas do conhecimento. Seja na política, na advocacia ou em um ambiente empresarial, a capacidade de persuasão está presente em nosso cotidiano em diversas situações. Conforme o dicionário Michaelis (2017) a palavra argumentação é definida como ato ou efeito de argumentar, onde por argumentar entende-se por apresentar fatos, provas ou argumentos, ou ainda, tirar as consequências de um princípio ou fato; concluir, deduzir.

Como destacado no capítulo anterior, vimos que na Grécia Antiga, uma das artes que compunha o Trivium era a Retórica. Neste âmbito, entendia-se por argumentação como um discurso destinado a convencer o próximo. Entretanto, com o surgimento da retórica moderna a argumentação assumiu um novo significado, onde, segundo Perelman ${ }^{13}$ (1977 apud D'AMORE, 2007, p.348), entende-se por argumentação "fornecer argumentos, isto é, razões a favor ou contra uma determinada tese". Desta forma, a argumentação é apenas uma parte de um discurso persuasivo, composto, segundo D'Amore (2008), por quatro partes: O Início, a Narração dos Fatos, a Argumentação (diferenciada em: confirmação ou demonstração ou prova, e refutação) e o Epílogo.

No decorrer dos anos que constituem a educação básica, em diversos momentos nos deparamos em situações que a argumentação, de acordo com a definição da retórica moderna, aparece no decorrer de uma aula. Podemos citar como exemplo quando estamos tratando o conceito de divisão. A afirmação "não existe divisão por zero no conjunto dos números naturais $\mathbb{N}$ ", é propicia a debates para verificar se a proposição é verdadeira ou falsa. Note que, em busca de fornecer argumentos, geralmente realizamos alguns exemplos simples, como por exemplo, $5 \div 0$. Espera-se de um aluno, que possua conhecimentos básicos sobre o significado de uma divisão e seu procedimento mecânico de resolução, tradicionalmente pelo método das chaves, apresente argumentos ao realizar alguns cálculos em que suponham o resultado.

${ }^{13}$ PERELMAN, C. Argomentazionre: verpete da Enciclopedia Einaudi. Torino:Einaudi. 1997. 
5

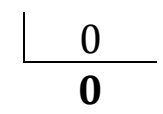

5

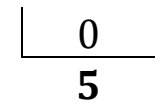

5

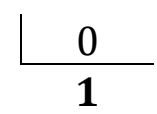

5

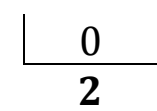

5

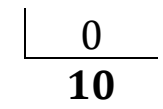

Não pode ser pois $\mathbf{0} \cdot 0 \neq 5$

Não pode ser pois $\mathbf{5} \cdot 0 \neq 5$

Não pode ser pois $\mathbf{1} \cdot 0 \neq 5$

Não pode ser pois $2 \cdot 0 \neq 5$

Não pode ser pois $10 \cdot 0 \neq 5$

A contradição da chamada prova real ${ }^{14}$, pode levar a um determinado grupo de alunos a se convencerem que realmente não existe divisão por zero em $\mathbb{N}$. Para alunos com conhecimentos em álgebra, a afirmação pode ser generalizada e reconhecida como verdadeira para qualquer elemento $n \in \mathbb{N}$, pois apoiam-se no fato, mesmo que intuitivo, de que vale $\forall n \in \mathbb{N} \Rightarrow n \cdot 0=0$, ou seja, qualquer número natural multiplicado por zero é igual a zero.

Uma outra característica da argumentação geralmente aparece quando estamos discutindo sobre o fato de não existir divisão por zero em $\mathbb{N}$. Se analisarmos o caso de $n=0$ podemos fornecer argumentos que contradizem a tese. Em um primeiro momento $0 \div 0$, é igual a 0 , pois satisfaz a definição de divisão, conforme justificativa abaixo:

0

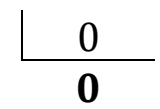

$\mathbf{0}$ é resultado pois $\mathbf{0} \cdot 0=0$

\footnotetext{
${ }^{14}$ Conhecida pelos alunos como prova real, Hefez $(2014$, p.53) remete a Euclides, na sua obra os Elementos, o fato de que sempre é possível efetuar a divisão de $a$ por $b$, com resto $r$. Chamada de Teorema da Divisão Euclidiana, é enunciado da seguinte forma: Sejam a e b dois números inteiros com $b \neq$ 0 . Existem dois únicos números inteiros $q$ e $r$ tais que $a=b q+r$, com $0 \leq r \leq|b|$
} 
Entretanto, analisando um pouco mais a expressão $0 \div 0$ percebe-se que 1 também é um resultado possível, pois satisfaz a definição de divisão, como segue abaixo:

0

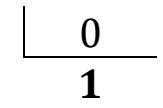

1 é resultado pois $1 \cdot 0=0$

De um modo geral esta ideia pode ser estendida para qualquer número natural, levando a concluir que existem infinitos resultados para $0 \div 0$, novamente apoiado no fato que todo número natural multiplicado por 0 é igual a 0 .

0

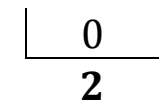

0

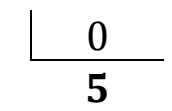

0

0

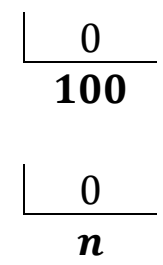

2 é resultado pois $2 \cdot 0=0$

$\mathbf{5}$ é resultado pois $\mathbf{5} \cdot 0=0$

100 é resultado pois $100 \cdot 0=0$

$\boldsymbol{n}$ é resultado pois $\forall n \in \mathbb{N} \Rightarrow n \cdot 0=0$

Baseados nestas duas argumentações perante a tese "não existe divisão por zero no conjunto dos números naturais $\mathbb{N}^{\prime \prime}$, notamos que ambas fornecem argumentos concisos, apoiados em conhecimentos prévios de matemática. Fato é que se, incluirmos a condição de que "existe um único resultado para uma divisão em $\mathbb{N}$ ", ambas argumentações podem levar a validação da tese, sendo desta forma aceita pelo público em questão.

Sendo assim, nota-se uma diferença entre o que vem ser uma argumentação e uma demonstração. Fato é que ambas fazem parte do cotidiano do ensino de matemática, entretanto, possuem características próprias, cujas finalidades de suas ações divergem em termos de produto final. 
Na argumentação tem-se a apresentação de várias teses e a sua verificação ou refutação com simples raciocínios, com exemplos imediatos ou com provas experimentais. E isso está em contraposição às demonstrações, que demandam, por outro lado, raciocínios articulados e muitas vezes distantes da verificação intuitiva imediata (MARCHINI ${ }^{15}, 1987$, apud D'AMORE,2007, p.351).

Segundo Becchere, Grunetti, Puxeddu e Uselli ${ }^{9}$ (1996 apud D'AMORE,2007) a argumentação pode levar em conta o contexto na qual se desenvolve; desta forma apoia-se na lógica natural, onde os argumentos em questão podem ser a favor de uma tese em um determinado momento, e contra, em outro. Em uma argumentação pode haver um estilo narrativo, considerações a ética e a fatos fora do tema em questão. Estas ações não pertencem a uma demonstração, que se baseia na lógica formal, é atemporal e não depende do momento na qual está sendo desenvolvida.

\footnotetext{
Uma demonstração formal é correta ou não correta, não há meio termo. E se é correta, é autossuficiente, não há nada a acrescentar. Pelo contrário, uma argumentação não tem jamais o rigor constritor de uma "boa" demonstração. A sua validade é uma questão de "grau": é mais ou menos forte. Por isso, uma argumentação está jamais fechada: podemos sempre pensar em reforça-la, acumulando argumentos convergentes(...) a argumentação é comparável a um tecido cuja solidez global supera aquela de cada um dos fios que o compõe. (BECCHERE, GRUNETTI, PUXEDDU e USELLI ${ }^{16}, 1996$, apud D'AMORE,2007, p.351)
}

D’Amore (2008) esboça as principais diferenças entre argumentação e demonstração através da tabela abaixo, ressaltando que trata da demonstração usual da prática matemática, que difere da lógica matemática

\footnotetext{
${ }^{15}$ MARCHINNI, C. Argumentazione e dimostrazione. L'insegnamento della matemática e delle scienze integrate.10,2,121-140. 1987

16 ECCHERE, GRUNETTI, PUXEDDU e USELLI. Argomentare e dimostrare. Una problematica “interdisciplinare” 1996.
} 
Tabela 2 - Principais diferenças entre Argumentação e Demonstração

\begin{tabular}{|c|c|c|}
\hline & Argumentação & Demonstração \\
\hline $\begin{array}{l}\text { Passagem de uma } \\
\text { proposição para a } \\
\text { outra }\end{array}$ & $\begin{array}{l}\text { Usam-se as regras implícitas que } \\
\text { dependem das estruturas linguísticas } \\
\text { e das representações escolhidas; } \\
\text { entra em jogo a metalinguagem e o } \\
\text { significado de cada proposição; } \\
\text { estamos, portanto, em plena fase de } \\
\text { semântica. }\end{array}$ & $\begin{array}{l}\text { Usam-se as regras de derivação que } \\
\text { devem (deveriam) ser explicitadas ou } \\
\text { acordadas previamente; as proposições } \\
\text { não veiculam conteúdos semânticos } \\
\text { particulares, mas intervêm pelo seu papel } \\
\text { (exemplo: premissa, consequência), passo } \\
\text { a passo, no decorrer da demonstração. }\end{array}$ \\
\hline Papel da Proposição & $\begin{array}{l}\text { Toda proposição tem um papel que } \\
\text { depende do seu conteúdo retórico. }\end{array}$ & $\begin{array}{l}\text { Muda ou pode mudar de acordo com a } \\
\text { situação e isso depende do quadro } \\
\text { teórico. }\end{array}$ \\
\hline $\begin{array}{l}\text { Papel dos conectores } \\
\text { que ligam as } \\
\text { proposições }\end{array}$ & $\begin{array}{l}\text { Os conectores são os mesmos da } \\
\text { linguagem natural e a sua função é a } \\
\text { de manifestar a relação entre a } \\
\text { proposições (exemplos: uma } \\
\text { proposição é consequência de outra, } \\
\text { ou a justifica, ou a contradiz, ou se } \\
\text { opõe a ela...) }\end{array}$ & $\begin{array}{l}\text { Os conectores são sempre retirados da } \\
\text { língua natural, mas são apenas } \\
\text { operadores que agem sobre as } \\
\text { proposições não tanto pelo que elas } \\
\text { veiculam de um ponto de vista semântico, } \\
\text { mas sim pelo seu estado operatório; } \\
\text { portanto, podem às vezes, ser omitidos ou } \\
\text { subentendidos. }\end{array}$ \\
\hline $\begin{array}{l}\text { Modalidade de } \\
\text { encandeamento entre } \\
\text { proposições }\end{array}$ & $\begin{array}{l}\text { Ocorre por conexão extrínseca, por } \\
\text { acumulação, agregam-se umas às } \\
\text { outras }\end{array}$ & $\begin{array}{l}\text { Ocorre pela substituição, como em um } \\
\text { cálculo, aplicando regras; as novas } \\
\text { proposições tomam o lugar, substituem as } \\
\text { precedentes }\end{array}$ \\
\hline
\end{tabular}

Fonte: D'Amore (2008, p.356)

A demonstração é considerada fundamental para as disciplinas de matemática a nível superior e a prática dos matemáticos. Na escola básica, em particular no ensino médio, a argumentação e a demonstração desempenham um papel importante na formação do aluno, pois favorece o desenvolvimento da autonomia intelectual, do espírito crítico, e na formação de opiniões, características essenciais para estarmos apto para iniciar nossa vida adulta. 
Entretanto o teor de rigorosidade de uma demonstração cria uma barreira que a torna quase que inacessível aos alunos da escola básica. Knuth ${ }^{17}$ (2002 apud HEALY; JAHN, 2008, p.1) descreve a que existe uma "tendência de professores de matemática em considerar a prova como um procedimento pedagógico limitado e não como uma forma de fazer matemática ou um meio de se comunicar matematicamente".

Da mesma maneira a argumentação muitas vezes não é trabalhada em sala de aula devido a diversos fatores como ênfase em lecionar matemática com foco na aplicação de procedimentos práticos, preocupação com o cumprimento de uma grande quantidade de conteúdos e até mesmo a desmotivação para lecionar que atinge a alguns professores

Um outro problema que pode inibir tal tratamento é em relação ao significado de uma demonstração matemática. No âmbito escolar, raramente é percebida pelos alunos quanto por muitos professores como uma ferramenta para a aprendizagem significativa, no ponto de vista da formação integral, da matemática; pelo contrário, as demonstrações matemáticas geralmente são percebidas pelos professores e alunos como um exercício formal e muitas vezes sem sentido para ser feito - pois não tem aplicação prática e por tanto, não serve para nada. Entretanto, De Villiers ${ }^{18}$ (2002, apud AMOULOUD et. al., 2008, p.216) destaca que o papel da demonstração exerce outras funções que podem contribuir para a formação do indivíduo e despertar um possível interesse pela matemática.

i. Verificação: convencimento próprio e dos outros a respeito da veracidade de uma afirmação;

ii. Explicação: compreensão do por que uma afirmação é verdadeira;

iii. Descoberta: de novas teorias, conjecturas ou resultados a partir da tentativa de se demonstrar uma conjectura;

iv. Comunicação: negociação do significado de objetos matemáticos;

v. Desafio intelectual: satisfação pessoal pelo êxito na demonstração de um teorema;

\footnotetext{
${ }^{17}$ KNUTH, E. Teachers' conceptions of proof in the context of Secundary School of Mathematics. Journal of Mathematics Teachers Education, 2002. 5(1), pp. 61-88.

${ }^{18}$ DE VILLIERS, M. Para uma compreensão dos diferentes papéis da demonstração em geometria dinâmica. Trad. Rita Bastos. ProfMat 10, Visue, Portugal. Actas... (CD-ROM) Visue, Associação de Professores de $\quad 2002$ Matemática, Disponível em:<http://mzone. mweb.co.za/residents/profmd/homepage.html>. Acesso em: 17 set. 2006.
} 
vi. Sistematização: organização de resultados em um sistema dedutivo de axiomas, conceitos e teoremas.

A escolha de atividades que motivem os alunos do ensino médio a trabalharem a argumentação e a demonstração em sala de aula é fundamental para que se reconheça sua importância. Práticas de ensino que possuem o professor com papel de detentor do conhecimento, onde o aluno assume um papel passivo no processo de ensino aprendizagem, podem não utilizar todo o potencial que possui a argumentação e a demonstração.

Desta forma, podemos entender as tendências previamente apontadas por Knuth. Considerando que o ensino direto é uma prática tradicional adotada por uma boa parte dos professores de todos os níveis de ensino, esta, talvez, não seja a forma mais apropriada de trabalharmos a argumentação e demonstração no ensino médio. Se simplesmente reproduzirmos uma demonstração na lousa para mostrar a validade de uma certa proposição, o aluno cumprirá sua função: prestará atenção, copiará no caderno para futuro estudos e, mesmo que intervenha em algum momento, continuará com seu papel passivo.

Fazer do aluno um sujeito com espirito crítico e produtor do próprio conhecimento, com o professor fazendo um papel de mediador, e não de detentor do conhecimento, é uma prática que pode colaborar muito para que se atinja os objetivos do Ensino Médio, podendo colaborar de forma significativa em uma melhor preparação dos alunos para enfrentarem os desafios do Ensino Superior. Segundo Faundez e Freire (1998, p.46)

“[...] o que o professor deveria ensinar - por que ele próprio deveria sabe-lo seria, antes de tudo, ensinar a perguntar. Porque o início do conhecimento, repito, é perguntar. E somente a partir de perguntar é que se deve sair em busca de respostas e não o contrário". 
De fato, cada vez mais nos conscientizamos que a adoção do ensino direto, em muitos casos, pode não desenvolver todo potencial do aluno no processo de ensino e aprendizagem, limitando sua produção de conhecimento, sua postura mediante aos estudos e, consequentemente, na sua formação. Sendo assim, em caráter contemporâneo, o professor

[...] assume um papel muito importante e duradouro juntos aos seus alunos no que diz respeito ao conhecimento: colaborar para que o aluno aprenda a buscar informações, detectar as fontes atuais dessas informações, dominar o caminho para acessá-las, aprender a selecioná-las, compará-las, criticá-las e integrá-las ao seu mundo intelectual (MASETTO, 2010, p.68).

Desta forma, as práticas pedagógicas apoiadas em atividades de investigação podem redesenhar o papel da demonstração e da argumentação em sala de aula, procurando desta forma contribuir significativamente para a formação dos alunos do Ensino Médio, auxiliando a:

i. Desenvolver e aprofundar os conhecimentos matemáticos;

ii. Desenvolver a autonomia intelectual e pensamento crítico, validando ou refutando intuições através de argumentos e provas;

iii. Compreender fundamentos científicos tecnológicos da produção do conhecimento matemático, construindo novos conceitos a partir de outros

iv. Desenvolver a iniciativa, criatividade na elaboração de estratégias e outras capacidades pessoais frente a desafios propostos

Além de poderem contribuir para o desenvolvimento de tais objetivos pertinentes ao ensino médio, as atividades de investigação que envolvem argumentação e demonstração podem minimizar os efeitos da transição para o ensino superior, auxiliando a: 
i. Desenvolver os níveis de competência em matemática, simplicidade técnica, capacidade analítica e percepções sobre o rigor e papel da prova em matemática;

ii. Melhor preparação dos alunos da escola básica perante a postura a aprendizagem autônoma

iii. Aproximar as práticas exercidas nas universidades, incentivando a pesquisa e investigação para a produção do conhecimento.

Com vista nos argumentos apresentados, propomos uma aplicação de atividade investigativa com o intuito de analisar o processo de construção do conhecimento por parte dos alunos de tal forma que indiciem ou refutem as capacidades apresentadas acima.

De acordo com o atual currículo, sabemos que a matemática do ensino médio trata de conteúdos de diversas áreas como geometria, álgebra, teoria dos conjuntos e estudo de funções, além de análise combinatória e probabilidade. Sabemos que essas áreas, hoje, possuem uma estrutura axiomática que validam os teoremas que fazem parte do ensino médio.

Em contrapartida, nem sempre os alunos ingressantes do ensino médio, tiveram uma experiência que validassem uma fórmula ou um fato matemático no ensino fundamental II, limitando-se ao nível de explicação proposto por Balacheff. Por se tratar de um tema que aparece no final do ensino fundamental II e se estende até o ensino superior, foi escolhido como tema o estudo de funções, em particular, o seu crescimento e decrescimento, que será melhor justificado no capítulo seguinte. 


\section{Capítulo 4}

\section{Uma proposta de investigação sobre a demonstração matemática.}

\subsection{A escolha do assunto.}

O conceito de função é um dos assuntos mais importantes da matemática. Tanto internamente, como nos estudos relacionados a Teoria de Conjuntos e Análise, quanto em outras áreas do conhecimento, as funções constituem uma teoria de certa relevância na construção de conhecimentos, de tal forma que as primeiras ideias aparecem ainda no Ensino Fundamental II e se estendem até o Ensino Superior.

No que tange ao Ensino Médio, espera-se que sua abordagem tenha como intuito servir de "[...] modelo para a compreensão de fenômenos variados" (BRASIL, Ministério da Educação, 2014, p.29) , contribuído desta forma para a formação integral, onde sua relação com outras áreas do conhecimento como Física, Química, Engenharia e Astronomia é essencial para a compreensão de fenômenos científicos e tecnológicos; No Ensino Superior, a ideia de sua abordagem nos cursos inicias de graduação é bem próxima ao do Ensino Médio. O aspecto variacional também é uma competência a ser trabalhada no estudo de Cálculo e disciplinas afins.

[...] umas das especificidades do cálculo, ao desenvolver estudos de funções, é a de estudar a taxa de variação de uma função, ou seja, diferentes maneiras pela qual uma função cresce ou decresce num intervalo ou num determinado ponto do intervalo. [...] nessa perspectiva, o cálculo é uma ferramenta extremamente útil, pois a variação de grandezas e a necessidade de aproximações locais é uma problemática presente em praticamente todas as áreas do conhecimento (BARUFI, 1999, p.3). 
Entretanto, quando se inicia o estudo de funções, geralmente a abordagem de caráter estático ${ }^{1}$ e operatório predomina e estende-se até o final do ensino médio, criando uma problemática referente a etapa de transição do ensino médio para o superior.

\begin{abstract}
Mesmo o ensino de funções, que tem início no final do Ensino Fundamental, segue uma abordagem mais substantiva, que meramente expõe a forma dos gráficos e a interpretação de alguns coeficientes. Raros são os momentos em que se destacam processos de modelagem, nos quais as variações das funções são consideradas de forma central. Esse, sim, é um dos pontos problemáticos do nosso Ensino Médio. Em um curso de cálculo, o foco deve se dar sobre a matematização, a análise e a síntese das relações variacionais (MOTTA, 2014, p.4).
\end{abstract}

Baseado neste propósito, levantou-se a hipótese de realizar uma atividade de investigação, cujo tema é crescimento e decrescimento de uma função afim. O objetivo desta atividade é de que os alunos relacionem o coeficiente angular de uma função afim com o fato de ser crescente ou decrescente, trabalhando em uma sequência didática ${ }^{2}$ de modo que produzam uma prova para as seguintes proposições:

Proposição 1: Se o coeficiente angular for positivo, então a função afim é crescente.

Proposição 2: Se o coeficiente angular for negativo, então a função afim é decrescente.

Como público alvo, foram escolhidas duas turmas de 1을 Ano do Ensino Médio de uma escola particular da cidade de São Paulo. As atividades forma aplicadas no início do 20 trimestre de 2017, e tiveram a duração de três aulas. Em relação ao modo de trabalho de sala de aula, a atividade foi realizada em grupos de no máximo 4 alunos, onde cada grupo

\footnotetext{
${ }^{1}$ Em contraposição ao caráter variacional; sem enfoque no estudo de crescimento e decrescimento de funções através de taxas de variação.

2 Sequencia didática é "um conjunto de atividades ordenadas, estruturadas e articuladas para a realização de certos objetivos educacionais, que tem um princípio e um fim conhecidos tanto pelos professores como pelos alunos" (ZABALA, 1998, p.18).
} 
tinha como ferramenta adicional para a investigação um computador com o software Geogebra ${ }^{3}$.

No momento da aplicação da atividade, os alunos possuíam conhecimentos prévios em relação a linguagem de conjuntos, conceito de função e diferentes formas de representação (algébrica, figural e gráfica), apresentados no decorrer do 10 trimestre letivo deste mesmo ano. Em particular, no estudo de função afim, possuem como conhecimento sua definição $\begin{aligned} f: \mathbb{R} & \rightarrow \mathbb{R} \\ x & \rightarrow f(x)=a x+b\end{aligned}$, onde $a \in \mathbb{R}^{*}$ e $b \in \mathbb{R}$, coeficiente angular, coeficiente linear e zero da função $x=-\frac{b}{a}$.

Em relação ao gráfico da função afim, os alunos sabem que a curva característica descreve uma reta com inclinação $\alpha$ em relação ao eixo $x$ dado por $a=\frac{f\left(x_{2}\right)-f\left(x_{1}\right)}{x_{2}-x_{1}}=\tan (\alpha)$.

Previamente ao início da atividade de investigação, foi definido o conceito de função crescente e decrescente da seguinte forma:

Definição: A função $\begin{aligned} f: A & \rightarrow B \\ x & \rightarrow f(x)\end{aligned}$ é crescente em um conjunto $I \subset A$ se, para dois valores quaisquer $x_{1}, x_{2} \in I$, com $x_{2}>x_{1}$, tivermos $f\left(x_{2}\right)>f\left(x_{1}\right)$.

Resumidamente, $f$ é crescente quando $\left(\forall x_{1}, x_{2}\right)\left(x_{2}>x_{1} \Rightarrow f\left(x_{2}\right)>f\left(x_{1}\right)\right)$

Definição: A função $\begin{aligned} f: & A \rightarrow B \\ & x \rightarrow f(x)\end{aligned}$ é decrescente em um conjunto $I \subset A$ se, para dois valores quaisquer $x_{1}, x_{2} \in I$, com $x_{2}>x_{1}$, tivermos $f\left(x_{2}\right)<f\left(x_{1}\right)$.

Resumidamente, $f$ é decrescente quando $\left(\forall x_{1}, x_{2}\right)\left(x_{2}>x_{1} \Rightarrow f\left(x_{2}\right)<f\left(x_{1}\right)\right)$

${ }^{3}$ Software de Geometria Dinâmica utilizado para o estudo funções, geometria plana e espacial, álgebra, cálculo, estatística. Site: https://www.geogebra.org/. 
Exemplos com funções reais diversas, que passassem a ideia de que "se conforme aumentar $x$, aumentar $f(x)$, então a função é crescente" e que "se conforme aumentar $x$, diminuir $f(x)$, então a função é decrescente" foram trabalhados em sala de aula de forma expositiva com o Geogebra.

\subsection{Estrutura de desenvolvimento da atividade de investigação}

De acordo com a estrutura para a aplicação da atividade, seguimos a estrutura dividida em três etapas apresentada previamente por Christiansen e Walther (1986, apud Ponte, 2010).

4.2.1 Apresentação da atividade e sua interpretação pelos alunos.

Na 1a aula da atividade de investigação, os grupos foram formados e alocados em uma estação de trabalho com um computador. Cada grupo recebeu uma atividade em papel onde fizeram os registros escritos.

Logo em seguida foi feita a apresentação da atividade aos alunos, onde foi explicado qual era o objetivo - realizar uma provar das proposições 1 e 2 - e o método de trabalho a ser praticado. As duas proposições aparecem no início da atividade, onde houve uma motivação com a seguinte pergunta: O que o coeficiente angular de uma função afim tem a ver com o crescimento e decrescimento de uma função? 
Figura 8 - Atividade de Investigação - Apresentação e Objetivos.

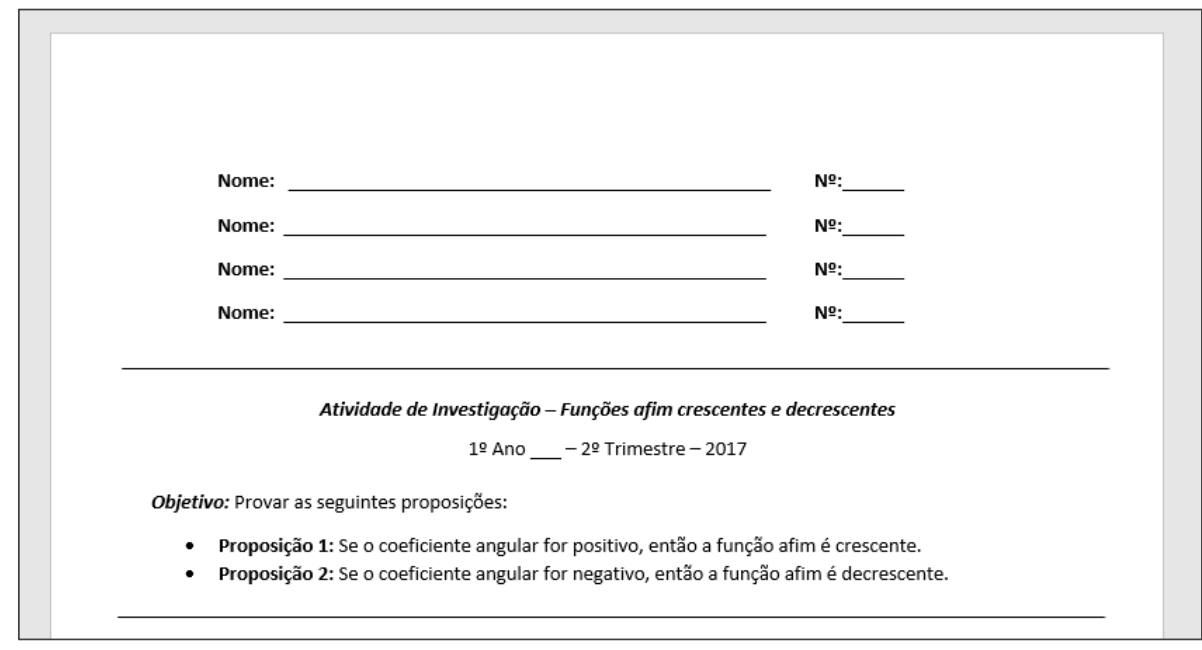

Fonte: Próprio Autor.

\subsubsection{Desenvolvimento do trabalho pelos alunos.}

A atividade de investigação consiste em 3 partes - a primeira, chamada de conjecturando tem como objetivo fazer os alunos perceberem graficamente que se o coeficiente angular da função afim for maior que zero, então teremos uma função crescente e, por outro lado, se o coeficiente angular da função afim for negativo, então teremos uma função decrescente. Para isso, uma pergunta motivadora foi feita para iniciarmos a atividade: - analisando graficamente, quando uma função afim é crescente? Quando é decrescente? Justifique a sua resposta.

Figura 11 - Atividade de Investigação - Questão Motivadora 
Figura 9 - Atividade de Investigação - Questão Motivadora.

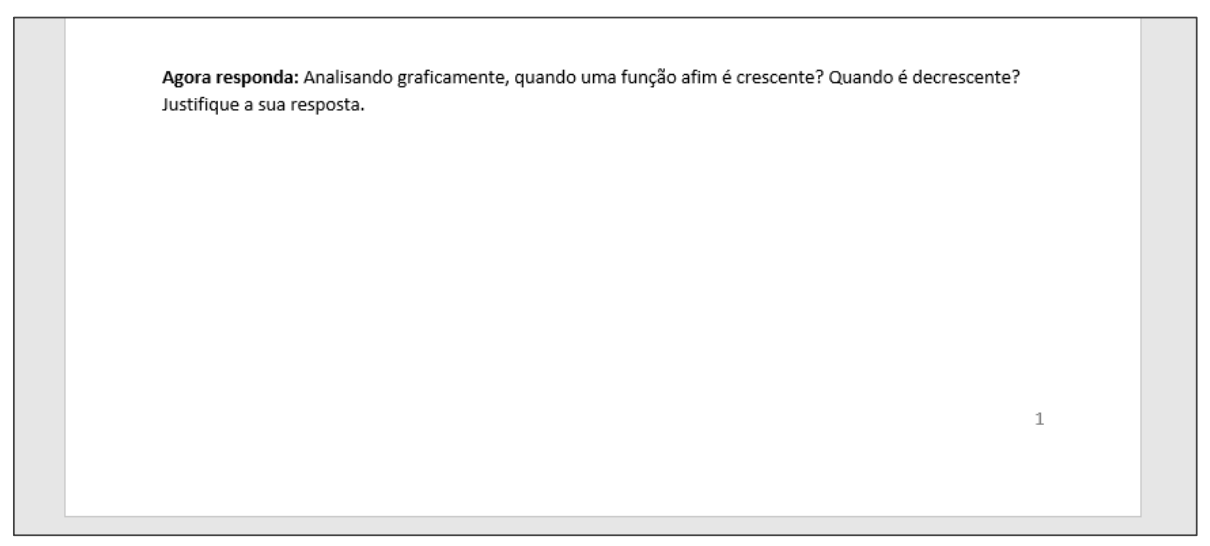

Fonte: Próprio Autor.

Para realizar a conjectura das duas proposições a serem provadas, o Geogebra foi utilizado como uma ferramenta para auxiliar a visualização dos fatos questionados. Desta forma os alunos foram instruídos a digitar a lei de formação da função afim, conforme apresentada em sala $f(x)=a x+b$ na caixa de entrada (input) com o intuito de criar controles deslizantes. Através deles podemos alterar os valores do coeficiente angular e linear, de tal forma que ocorra o processo investigativo, através de uma análise gráfica dinâmica.

A segunda parte, chamada de função afim crescente tem como objetivo conduzir o aluno a desenvolver uma prova da Proposição 1 - Se o coeficiente angular for positivo, então a função afim é crescente - de tal forma que passem pelas quatro etapas propostas por Balacheff, esperando que faça a passagem da prova pragmática para a intelectual.

No item 1, os alunos tomam como exemplo a função afim $f(x)=2 x+1$ com o intuito de verificar se a função admite um comportamento de função crescente. Desta forma, escolhendo-se valores aleatórios para $x_{1}$ e $x_{2}$ de tal forma que se tenha $x_{2}>x_{1}$, espera-se que ele calcule ou analise graficamente no Geogebra os valores de $f\left(x_{1}\right)$ e $f\left(x_{2}\right)$, verifique que acontece a implicação $f\left(x_{2}\right)>f\left(x_{1}\right)$, e conclua que caracteriza uma função crescente. 
Figura 10 - Atividade de Investigação - item 1 - comportamento empirista ingênuo.

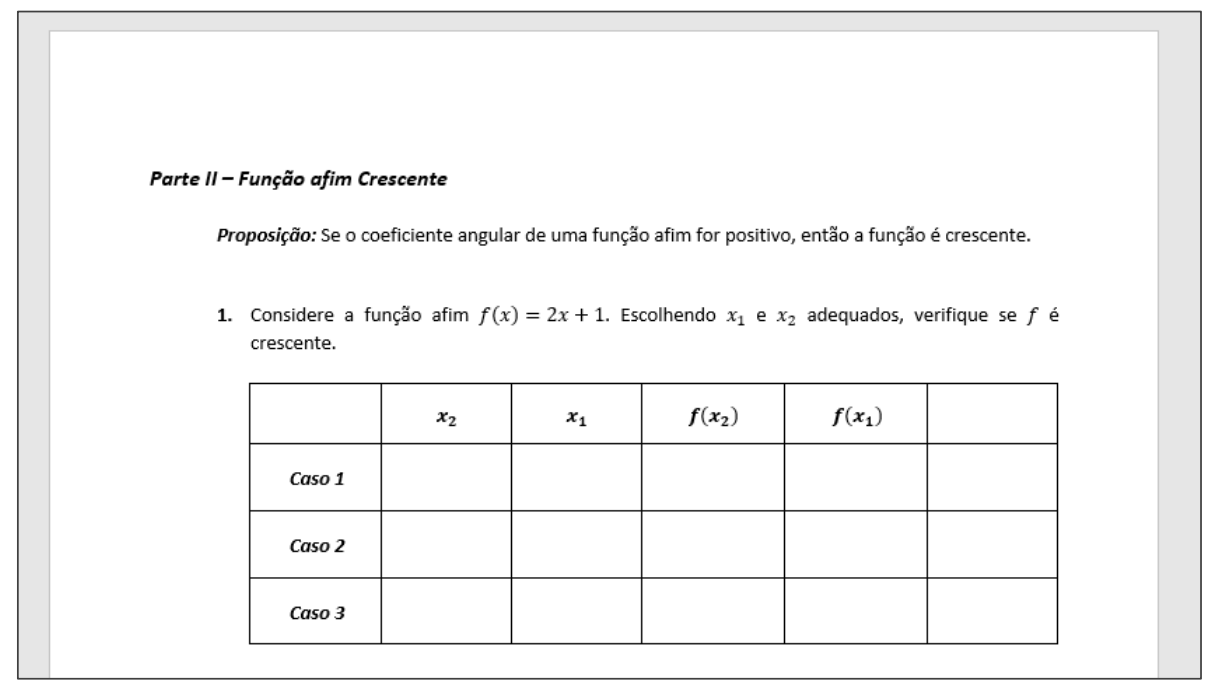

Fonte: Próprio Autor.

Um exemplo de resolução esperada é conforme tabela abaixo. Por ser tratar de uma atividade de investigação, possui um caráter aberto, onde os valores escolhidos podem variar de acordo com a escolha do grupo. Entretanto espera-se que neste item os alunos atuem conforme o comportamento empirista e ingênuo.

Tabela 3 - Atividade de Investigação - exemplo de resolução para o item 1

\begin{tabular}{|c|c|c|c|c|c|}
\hline & $x_{2}$ & $x_{1}$ & $f\left(x_{2}\right)$ & $f\left(x_{1}\right)$ & \\
\hline Caso 1 & 2 & 1 & 5 & 3 & $\sqrt{ }$ \\
\hline Caso 2 & 5 & 3 & 10 & 7 & $\sqrt{ }$ \\
\hline Caso 3 & -1 & -4 & -1 & -7 & \\
\hline
\end{tabular}

Fonte: Próprio Autor.

No item 2, espera-se que os alunos realizem a pesquisa do experimento crucial, ou seja, aumentando a faixa dos valores possíveis para o coeficiente angular, o aluno pode verificar dinamicamente através do Geogebra que, independentemente do valor do coeficiente angular escolhido, mantendo a condição $a>0$, a função afim se manterá crescente. 
Figura 11 - Atividade de Investigação - item 2 - experimento crucial.

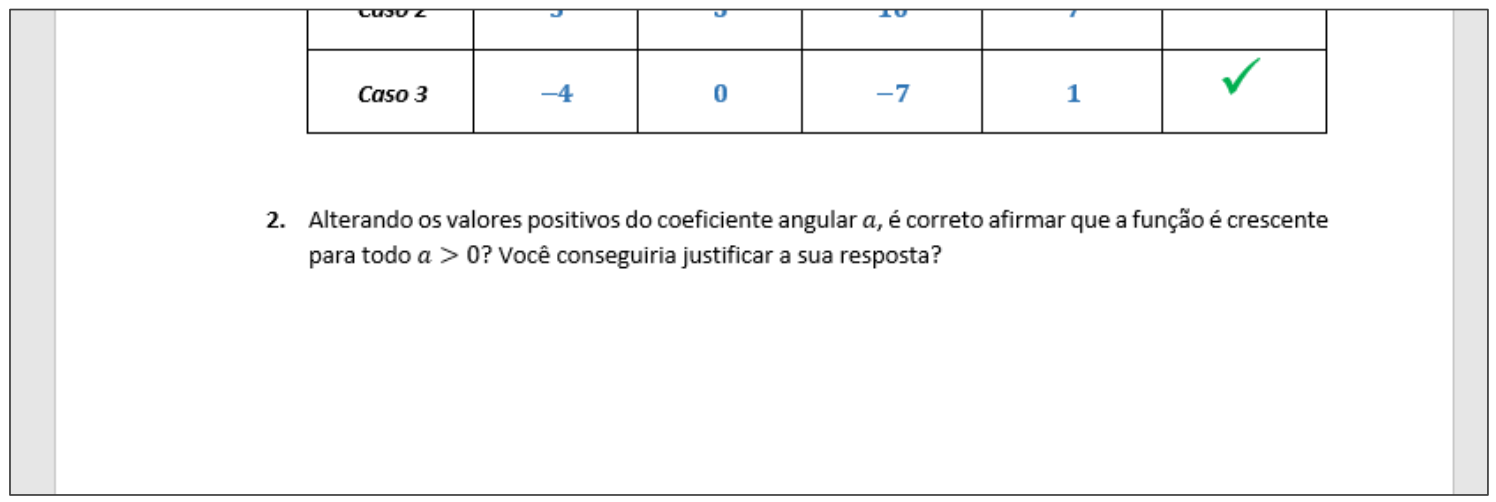

Fonte: Próprio Autor.

Nos itens 3, 4 e 5, o objetivo é fazer com que o aluno faça a generalização do exemplo, construindo de uma certa forma uma classe de objetos característico da função crescente. Assim, primeiramente espera-se que o aluno verifique no item 3 que a diferença dos valores escolhidos para $x_{1}$ e $x_{2}$, nos três casos do item 1 , é sempre positivo.

Figura 12 - Atividade de Investigação - item 3 - generalização do exemplo.

3. Calcule a diferença $x_{2}-x_{1}$ para os casos escolhidos no item 1 .

\begin{tabular}{|c|c|}
\hline & $x_{2}-x_{1}$ \\
\hline Caso 1 & \\
\hline Caso 2 & \\
\hline Caso 3 & \\
\hline
\end{tabular}

Fonte: Próprio Autor.

Conforme valores adotados para o item 1, espera-se que tenha uma resolução da seguinte forma: 
Tabela 4 - Atividade de Investigação - exemplo de resolução para o item 3

\begin{tabular}{|c|c|}
\hline & $x_{2}-x_{1}$ \\
\hline Caso 1 & $2-1=1$ \\
\hline Caso 2 & $5-3=2$ \\
\hline Caso 3 & $-1-(-4)=3$ \\
\hline
\end{tabular}

Fonte: Próprio Autor.

Logo em seguida, no item 4, questionamos os alunos sobre a validade do fato da diferença $x_{2}-x_{1}$ ser sempre positiva. Desta forma espera-se que os alunos argumentem apoiando-se no fato que, se adotado $x_{2}>x_{1}$, então teremos $x_{2}-x_{1}>0$.

Figura 13 - Atividade de Investigação - item 4 - generalização do exemplo.

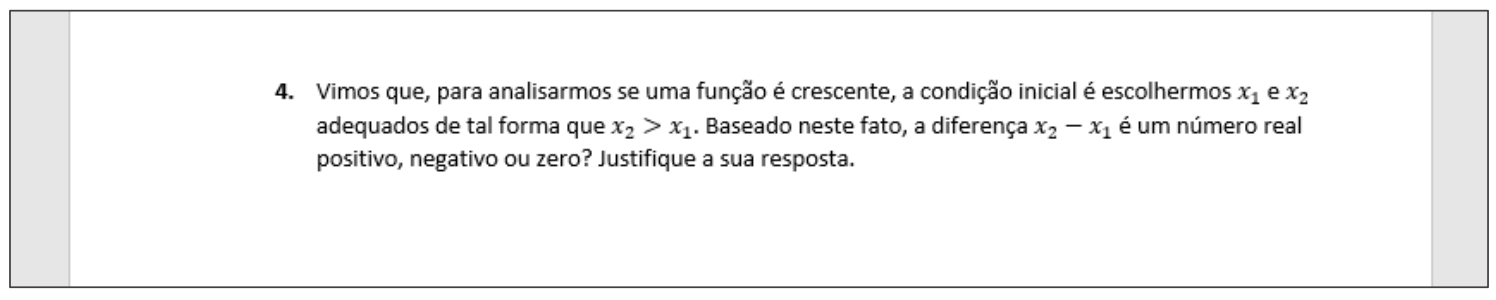

Fonte: Próprio Autor.

Finalizando a etapa de generalização do exemplo, usando o fato previamente apresentado $a=\frac{f\left(x_{2}\right)-f\left(x_{1}\right)}{x_{2}-x_{1}}$ e da validade de que $x_{2}-x_{1}>0$ espera-se que os alunos concluam que a diferença $f\left(x_{2}\right)-f\left(x_{1}\right)$ ser positiva é uma condição necessária para a função afim ser crescente.

Figura 14 - Atividade de Investigação - item 5 - generalização do exemplo.

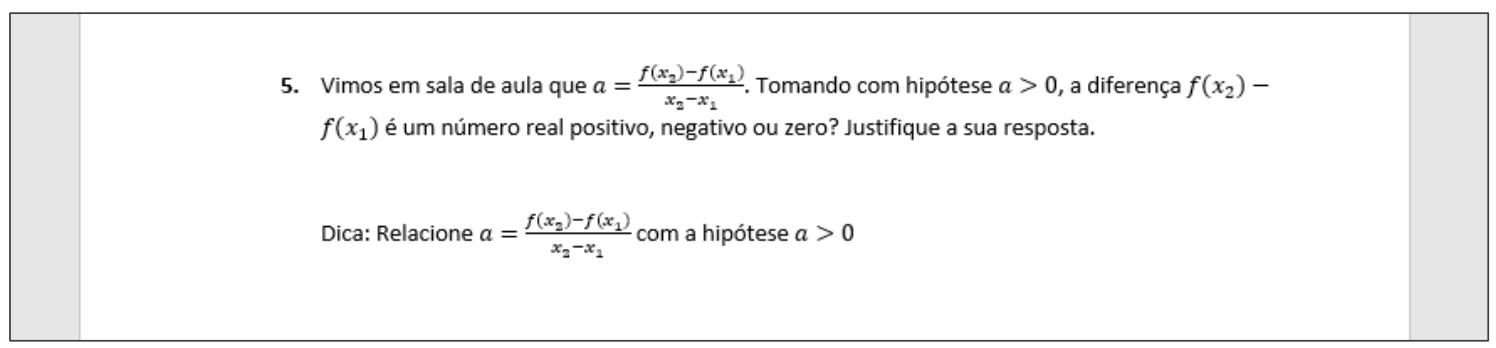

Fonte: Próprio Autor. 
Finalizando esta etapa da atividade de investigação, no item 6 espera-se que o aluno articule as ideias anteriores, realizando o experimento mental - etapa na qual desenvolve uma prova da proposição 1.

Figura 15 - Atividade de Investigação - item 6 - experimento mental.

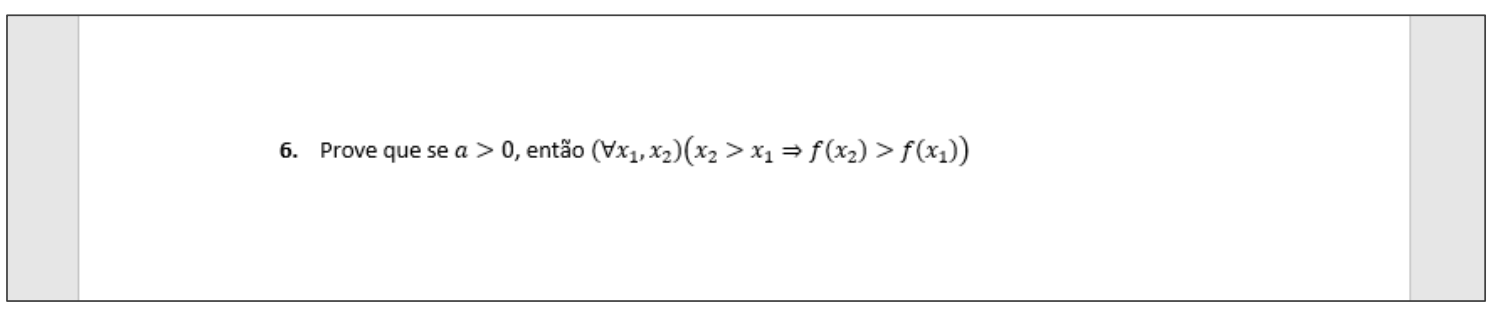

Fonte: Próprio Autor.

A etapa III, chamada de função afim decrescente, segue de modo análogo ao desenvolvimento da etapa II, entretanto espera-se que o aluno caminhe com uma maior autonomia. Um outro ponto a destacar é que nas etapas II e III alguns itens pedem para os alunos justificarem as suas respostas. A intenção é fazer que no meio do processo de investigação os alunos reflitam sobre o que estão produzindo no momento e os motivem a desenvolverem argumentos convincentes quando não conseguem realizar uma justificativa de algum fato matemático.

\subsubsection{Discussão e Síntese Final}

Em um último momento, antes de recolher as atividades de investigação, foi reservado uma parte da aula para a discussão e síntese final, com o intuito de promover o debate, confronto de ideias dos grupos, onde a argumentação sobre o desenvolvimento da atividade ganha espaço no ambiente de sala de aula, e por fim consolidar os conhecimentos adquiridos. 


\subsection{Aplicação e análise da atividade de investigação}

Com a aplicação da atividade de investigação nas duas turmas de 1 o ano do Ensino Médio, destaco nesta parte do trabalho alguns momentos relevantes durante seu desenvolvimento. Os registros das aulas, nas quais foram aplicas as atividades de investigação, foram feitos em dois formatos: i) Registro escrito das atividades; ii) Registro de áudio, com captação centralizada no professor

\subsubsection{Parte I-Conjecturando}

Durante a conjectura das proposições, notou-se que alunos conforme manipulavam diferentes valores para o coeficiente angular e visualizavam dinamicamente o comportamento gráfico da função afim, conseguiam relacioná-los com o fato de ser crescente ou decrescente, conforme diálogo abaixo.

Professor: Vocês conseguiram fazer?

Aluno A - Sim.

Professor: Explica para o professor então, o que vocês fizeram.

Aluno A: Quando o a é negativo vai ser decrescente. E quando o a for positivo vai ser crescente.

Figura 16 - Análise da atividade de investigação - Conjecturando

Agora responda: Analisando graficamente, quando uma função afim é crescente? Quando é decrescente? Justifique a sua resposta.

Buondo o valor de 'a" por postive será crescente, e quande $\theta$ "a" Por negatio sera decrescente.

Loso ocontece pais quonde o a í posetivo o " $y$ " oumento, e quando O"a". é negotivo o "y" é grodolwaminte menor 1 Fonte: Próprio autor. 
Alguns grupos de alunos, precisaram de ajuda do professor para conseguirem realizar a conjectura das proposições. Um breve auxilio os induziram a tirar as suas próprias conclusões.

Professor - Aumenta um pouquinho o (valor do coeficiente) $a$. Está crescente não está?

Aluno B - Sim

Professor - Joga para o negativo e vê o que acontece. Olha o que aconteceu com o gráfico... vocês entenderam?

Aluno B - Então a função é crescente quando $a$ é positivo?

Professor - Crescente quando $a$ é positivo.

Professor e Aluno B - E decrescente quando a é negativo.

Figura 17 - Análise da atividade de investigação - Conjecturando com auxílio do professor.

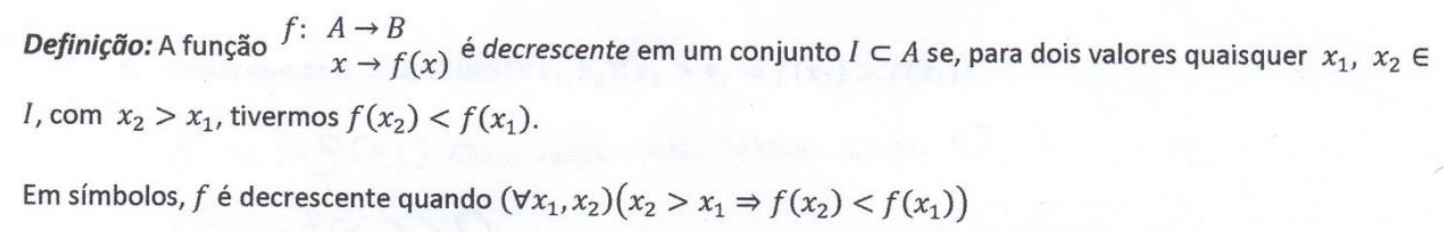

Agora responda: Analisando graficamente, quando uma função afim é crescente? Quando é decrescente? Justifique a sua resposta.

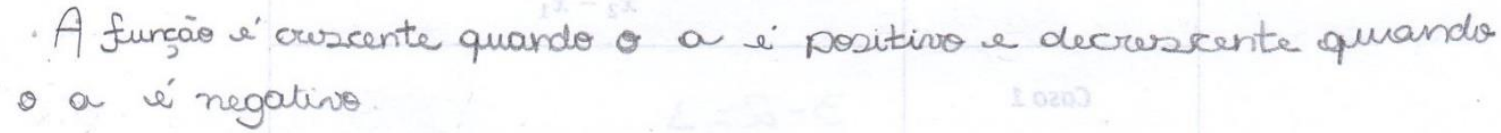

Fonte: Próprio autor

Um outro ponto a destacar nesta primeira etapa é em relação ao papel de uma prova para o aluno do Ensino Médio. O fato apontado que muitos alunos não reconhecem a necessidade de realizar uma prova aparece no momento a seguir.

Aluno C: - Como eu faço para explicar?

Professor: - Difícil, não é? Faz parte da atividade não conseguir explicar para vocês perceberem que a gente precisa arrumar alguns meios para argumentar este fato. Aluno C: - Vou responder "porque confio no Professor". 


\subsubsection{Parte II - Função afim crescente}

No item 1, os alunos não encontraram maiores dificuldades de preencher a tabela devido a familiaridade em saber calcular o valor numérico de uma função. 0 entendimento em relação a implicação que caracteriza uma função crescente $x_{2}>x_{1} \Rightarrow$ $f\left(x_{2}\right)>f\left(x_{1}\right)$ foi assimilado de forma satisfatória, mostrando que a etapa do comportamento empirista ingênuo é aparentemente familiar para o aluno, quando deseja verificar a validade de alguns casos particulares.

Figura 18 - Análise da atividade de investigação - Função afim crescente - Tabela do item 1

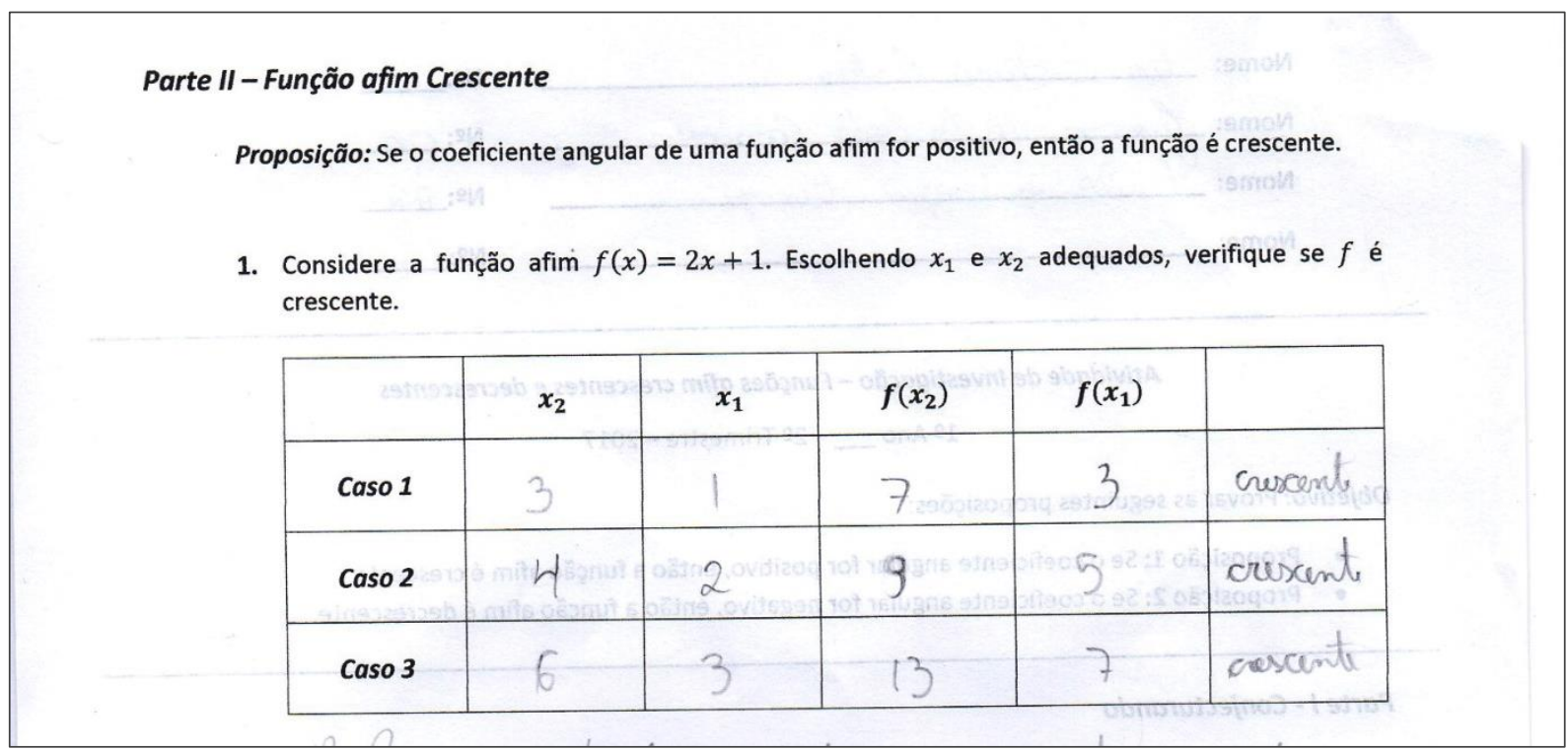

Fonte: Próprio autor.

No item 2, quando pedido para os alunos alterarem os valores do coeficiente angular de tal forma que $0<a<1000$ possibilitou que verificassem, através do controle deslizante e do comportamento gráfico, independentemente do valor positivo escolhido para o coeficiente angular $a$, a função será sempre crescente neste intervalo. Desta forma, a verificação da validade da proposição é feita conforme a etapa definida por pesquisa do experimento crucial.

Um ponto importante foi em relação aos valores do coeficiente angulares próximos a 1000. Alguns alunos tiveram a percepção da curva do gráfico ser uma reta 
vertical, apesar de não conseguirem fornecer argumentos sobre a impossibilidade de tal fato.

Aluno D: Está reto!

Professor: Qual tipo reta?

Aluno D: Vertical?!

Professor: Está certo! Mas por mais que pareça uma reta vertical, ela nunca vai ser.

Vocês conseguem justificar este fato?

Aluno E: Você chegou a explicar, mas...

Após discussão de ideias com o grupo, argumentaram a refutação da possibilidade de a reta estar em posição vertical da seguinte forma:

Figura 19 - Análise da atividade de investigação - Função afim crescente - Argumentação do item 2

2. Alterando os valores positivos do coeficiente angular $a$, é correto afirmar que a função é crescente para todo $a>0$ ? Você conseguiria justificar a sua resposta?

De a funcä permonecer com o" "a" portivo, sempru seró srescente. Pois a dfererso entu $x^{2}$ ex' (denomencolor) näs pode sa O,e so ai e reto duxorio de ser crescente eficoira pertico

Fonte: Próprio autor.

Nos itens 3, 4 e 5 - conjunto que leva os alunos a generalização do exemplo existiu uma maior dificuldade na execução dos desafios propostos. Apesar do item 3 terem sido feitos, do ponto de vista operatório, sem maiores problemas, alguns alunos questionaram o motivo pelo qual estava calculando a diferença $x_{2}-x_{1}$.

Em ambas as salas, foi feito neste momento, uma breve troca de ideias com o intuito de explicar o objetivo destes três itens referentes a esta etapa de generalização do exemplo. Quando estimulados a refletirem sobre o que deveria acontecer com o sinal de $f\left(x_{2}\right)-f\left(x_{1}\right)$, sabendo que $x_{2}-x_{1}>0$, para que a divisão $\frac{f\left(x_{2}\right)-f\left(x_{1}\right)}{x_{2}-x_{1}}$ seja positiva (devido 
a hipótese inicial $a>0$ ) boa parte dos alunos conseguiram assimilar a ideia e concluir que $f\left(x_{2}\right)-f\left(x_{1}\right)$ também teria que ser positivo.

Figura 20 - Análise da atividade de investigação - Função afim crescente - itens 4 e 5

4. Vimos que, para analisarmos se uma função é crescente, a condição inicial é escolhermos $x_{1}$ e $x_{2}$ adequados de tal forma que $x_{2}>x_{1}$. Baseado neste fato, a diferença $x_{2}-x_{1}$ é um número real positivo, negativo ou zero? Justifique a sua resposta.

Positiva, pois $\theta x_{2}>x_{1}$,

$x_{2}-x_{1}>0$

5. Vimos em sala de aula que $a=\frac{f\left(x_{2}\right)-f\left(x_{1}\right)}{x_{2}-x_{1}}$. Tomando como hipótese $a>0$, a diferença $f\left(x_{2}\right)-$ $f\left(x_{1}\right)$ é um número real positivo, negativo ou zero? Justifique a sua resposta.

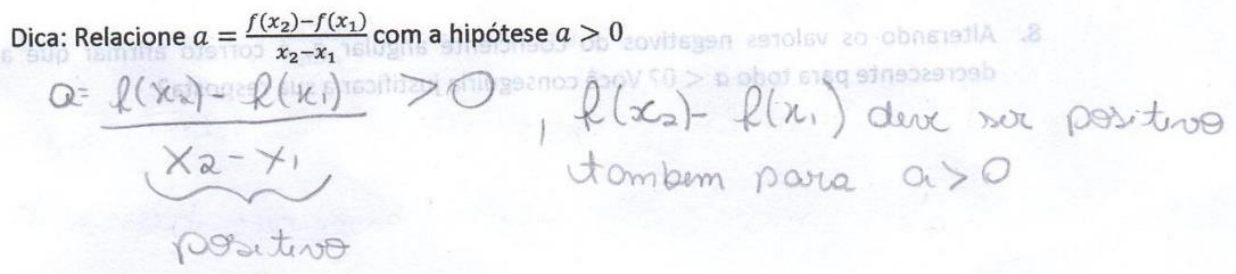

Fonte: Próprio autor.

Alguns alunos utilizaram, no item 4, a língua materna para argumentar em relação a ao fato de ser $x_{2}-x_{1}>0$.

Figura 21 - Análise da atividade de investigação - Função afim crescente - argumentação do item 4

4. Vimos que, para analisarmos se uma função é crescente, a condição inicial é escolhermos $x_{1}$ e $x_{2}$ adequados de tal forma que $x_{2}>x_{1}$. Baseado neste fato, a diferença $x_{2}-x_{1}$ é um número real positivo, negativo ou zero? Justifique a sua resposta.

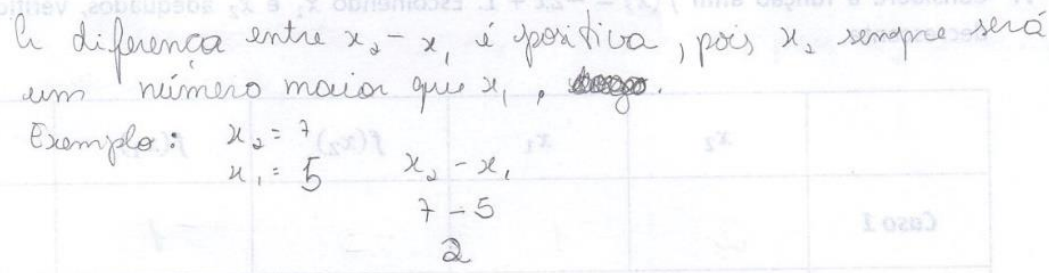


Em um último momento, quando os alunos ficaram frente a produzir uma prova para a proposição se $a>0$, então $\left(\forall x_{1}, x_{2}\right)\left(x_{2}>x_{1} \Rightarrow f\left(x_{2}\right)<f\left(x_{1}\right)\right)$, alguns foram coerentes e, com uma linguagem próxima da formal, concluíram a validade da proposição.

Figura 22 - Análise da atividade de investigação - Função afim crescente - item 6

6. Prove que se $a>0$, então $\left(\forall x_{1}, x_{2}\right)\left(x_{2}>x_{1} \Rightarrow f\left(x_{2}\right)>f\left(x_{1}\right)\right)$

$f\left(x_{2}\right)-f\left(x_{1}\right)>0$

$f\left(x_{2}\right)>f\left(x_{1}\right)$

6. Prove que se $a>0$, então $\left(\forall x_{1}, x_{2}\right)\left(x_{2}>x_{1} \Rightarrow f\left(x_{2}\right)>f\left(x_{1}\right)\right)$

$f\left(x_{2}\right)-f\left(x_{1}\right)$ tem que ser moior que $O$.

$f\left(x_{2}\right)-f\left(x_{3}\right)>0$

$f\left(x_{2}\right)>f\left(x_{1}\right)$

6. Prove que se $a>0$, então $\left(\forall x_{1}, x_{2}\right)\left(x_{2}>x_{1} \Rightarrow f\left(x_{2}\right)>f\left(x_{1}\right)\right)$

$\left(\forall x_{1}, x_{2}\right) \quad f\left(x_{2}\right)>f\left(x_{1}\right)$

$x_{2}>x_{1} \quad f\left(x_{2}\right)-f\left(x_{1}\right)>0$

$x_{2}-x_{1}>0$

Fonte: Próprio autor

\subsubsection{Parte III - Função afim decrescente}

Na parte III a maioria dos grupos de alunos conseguiram trabalhar de uma forma mais autônoma, pois intencionalmente o percurso de itens, que serve de guia para o desenvolvimento da atividade, é similar a parte II - função crescente. 
Figura 23 - Análise da atividade de investigação - Função afim decrescente

\section{Parte III - Função afim Decrescente}

Proposição: Se o coeficiente angular de uma função afim for negativo, então a função é decrescente.

7. Considere a função afim $f(x)=-2 x+1$. Escolhendo $x_{1}$ e $x_{2}$ adequados, verifique se $f$ é decrescente.

\begin{tabular}{|c|c|c|c|c|c|}
\hline & $\boldsymbol{x}_{\mathbf{2}}$ & $\boldsymbol{x}_{\mathbf{1}}$ & $\boldsymbol{f ( \boldsymbol { x } _ { \mathbf { 2 } } )}$ & $\boldsymbol{f}\left(\boldsymbol{x}_{\mathbf{1}}\right)$ & \\
\hline Caso 1 & -1 & -2 & 3 & 5 & decrexanto \\
\hline Caso 2 & -2 & -3 & 5 & 7 & decruxents \\
\hline Caso 3 & -3 & 4 & 7 & 9 & decowante. \\
\hline
\end{tabular}

8. Alterando os valores negativos do coeficiente angular $a$, é correto afirmar que a função é decrescente para todo $a<0$ ? Você conseguiria justificar a sua resposta?

De a volor de a permonecernegotire sempre seró decrercents

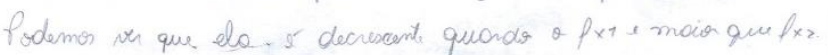

9. Calcule a diferença $x_{2}-x_{1}$ para os casos escolhidos no item 7 .

\begin{tabular}{|l|l|}
\hline & $x_{2}-x_{1}$ \\
\hline Caso 1 & 2 \\
\hline Caso 2 & 2 \\
\hline $\operatorname{caso} 3$ & 2 \\
\hline
\end{tabular}

10. Vimos que, para analisarmos se uma função é crescente, a condição inicial é escolhermos $x_{1}$ e $x_{2}$ positivo, negativo ou zero? Justifique a sua resposta.

Postivo,

$x_{2}>x_{1}$

11. Vimos em sala de aula que $a=\frac{f\left(x_{2}\right)-f\left(x_{1}\right)}{x_{2}-x_{1}}$. Tomando como hipótese $a<0$, a diferença $f\left(x_{2}\right)-$ $f\left(x_{1}\right)$ é um número real positivo, negativo ou zero? Justifique a sua resposta.

Dica: Relacione $a=\frac{f\left(x_{2}\right)-f\left(x_{1}\right)}{x_{2}-x_{1}}$ com a hipótese $a<0$

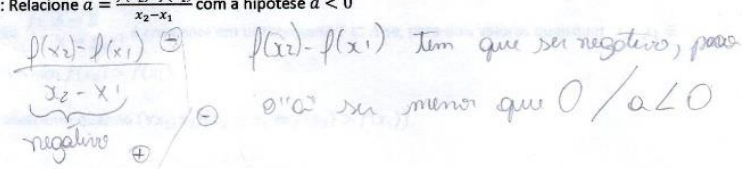

12. Prove que se $a<0$, então $\left(\forall x_{1}, x_{2}\right)\left(x_{2}>x_{1} \Rightarrow f\left(x_{2}\right)<f\left(x_{1}\right)\right)$

$f\left(x_{2}\right)-f\left(x_{1}\right)<0$

$f(x)<f(x)$

Fonte: Próprio autor. 
Em síntese final, as ideias dos grupos foram confrontadas em um espaço onde a argumentação teve papel fundamental na validação e construção do novo conhecimento proposto pela atividade. Desta forma, quando questionado os alunos o motivo pelo qual se $a>0(a<0)$ então a função crescente (decrescente), argumentos que visavam validar tal fato foram citados pelos alunos, podendo desta forma, ter ajudado a convencer quem não tinha assimilado tal conteúdo. 


\section{Considerações Finais}

Os resultados apontados por pesquisas aqui referidas constatam a problemática do ensino de matemática referente a etapa de transição entre o Ensino Médio e o Superior, idealizando a falta de conexão entre os dois níveis de ensino.

Se de um modo a contextualização e a interdisciplinaridade favorecem compreensão da relação entre a teoria e prática, a argumentação e demonstração contribui para uma implementação da autonomia intelectual, pensamento crítico, além da consolidação e construção de novos conhecimentos, aproximando-se da matemática abstrata.

Vimos que nem sempre são adotadas práticas de ensino de matemática na escola básica que tenham como foco a argumentação e demonstração. A ênfase em um ensino que privilegia aplicação de fórmulas e técnicas de cálculos meramente mecânicos, pode não desenvolver todo potencial de aprendizagem do aluno, por ser um trabalho com foco em uma única vertente da matemática, seu aspecto operacional.

Mas, se adotarmos uma postura baseada somente no ensino direto, as demonstrações não farão muito sentido para o aluno, assemelhando-se a uma mera explicação seguida de exercícios a serem realizados. Reforçando esta ideia, Ponte (2010, p.13) afirma que "ensinar matemática como um produto acabado, tem-se revelado problemático para sucessivas gerações de professores. Muitos alunos acham que a disciplina não faz qualquer sentido e que não vale a pena esforçarem-se para a aprender".

A escolha de atividades que motivem os alunos do ensino médio a trabalharem a argumentação e a demonstração em sala de aula é fundamental para que se reconheça sua importância e torne significativa em sua formação. Sendo assim, a resposta para a segunda questão norteadora desta pesquisa - Como poderíamos aproximar a matemática do ensino médio à matemática do ensino superior? - surge da ideia de 
relacionar a teoria de atividades investigativas proposta por Ponte em um contexto de prova proposto por Balacheff.

Com base nos estudos das duas teorias, acreditamos que uso de práticas pedagógicas apoiadas em atividades investigativas de modo que levem os alunos a produzirem suas próprias demonstrações, além de aproximar das práticas desenvolvidas no ensino superior, proporciona aos alunos uma forma de aprendizagem autônoma, com a possibilidade de elevar a capacidade em relação aos conhecimentos matemáticos, contribuindo desta forma em sua formação básica e preparando melhor para o ingresso nas universidades.

Com a aplicação da atividade investigativa envolvendo demonstração e argumentação, apontamos de um modo geral mais pontos positivos do que negativos. Primeiramente, a motivação por parte dos alunos foi diferente das aulas tradicionais; o fato deles receberem uma tarefa e trabalharem em busca da solução, fez com que houvesse um maior interesse, e consequentemente uma maior interação entre os alunos. A argumentação teve papel relevante no desenvolvimento da atividade em momentos de debates internos (grupo e professor) e da síntese final, onde os significados das proposições foram negociados em colaboração conjunta por parte de professor e alunos; ao realizar o confronto de ideias, os argumentos eram aceitos ou refutados por todos envolvidos na atividade, chegando desta forma em conclusões aceitas por consenso geral.

Além disso, quando tiveram de realizar a prova das proposições (I) se $a>0$, então $\left(\forall x_{1}, x_{2}\right)\left(x_{2}>x_{1} \Rightarrow f\left(x_{2}\right)>f\left(x_{1}\right)\right)$ e (II) se $a<0$, então $\left(\forall x_{1}, x_{2}\right)\left(x_{2}>x_{1} \Rightarrow\right.$ $\left.f\left(x_{2}\right)<f\left(x_{1}\right)\right)$, colocamos os alunos frente a desenvolver sua capacidade analítica, relacionando os conhecimentos prévios, de modo a produzir algo novo. Além disso, a atividade abriu espaço para discussões sobre o que seria uma hipótese, uma tese e uma relação de implicação. Mesmo que de um modo ingênuo, estes debates contribuirão para a evolução do aluno em matemática.

Outro fato relacionado a aplicação da atividade investigativa está na coerência com as principais dificuldades que os alunos apresentam no ensino superior. 
Notou-se que alguns alunos, dependiam do auxílio do professor que, mesmo com convicções coerentes, tinham a necessidade do aval para colocarem suas ideias no papel.

Em relação aos pontos negativos, podemos extrair que o principal foi em relação ao tempo. Foram dedicadas três aulas desde a apresentação até a síntese final, o que pode ser inviável em contextos escolares onde predomina-se a transmissão de uma grande quantidade de tópicos da matemática.

De um modo geral, atividades investigativas envolvendo a demonstração e argumentação podem aproximar os alunos do ensino médio à matemática do ensino superior, sempre tendo em vista a formação integração do aluno. Entretanto devemos ter em mente que a melhoria dos conhecimentos matemáticos e autonomia dos alunos são desenvolvidos de forma gradual, sendo necessário adotarmos o hábito de práticas investigativas envolvendo argumentação e demonstração no decorrer de todo caminho do ensino médio.

Claro que esse tema ainda tem muito campo de estudo a ser descoberto e como projeto futuro, essa pesquisa visa abrir uma porta para o desenvolvimento de atividades investigativas que envolvam demonstração nos diversos conteúdos da matemática do ensino médio. Acredito que a teoria de Balacheff associada com a teoria de Ponte, podem fornecer frutos para o desenvolvimento de atividades diferenciadas em matemática para o ensino médio que contribuam para a formação integral do aluno e, ao mesmo tempo, prepare para o ingresso no ensino superior. 


\section{Referências}

ALMEIDA, L. S. et al. Transição para o Ensino Superior. Braga: Universidade do Minho, Conselho Acadêmico, 2000.

ALMOULOUD A. S.; FUSCO, C. A. S.; MIGUEL, M. I. R.; SILVA, M. J. F. Formação de professores de Matemática e apreensão significativa de problemas envolvendo provas e demonstrações. Educ. Mat. Pesqui., São Paulo, v. 10, n. 2, pp. 217-246, 2008.

AZEVEDO, A. et. al. Investigações e explorações como parte do trabalho quotidiano na sala de aula. Amazônia Revista de Educação em Ciências e Matemáticas. v.9 (18) jan-jun 2013. pp.05-22.

BARUFI, M. C. B. A construção/negociação de significados no curso universitário inicial de Cálculo Diferencial e Integral. 1999. 195 f. Tese (Doutorado em Educação) - Faculdade de Educação, Universidade de São Paulo. São Paulo, 1999.

BRASIL. Ministério da Educação. Diretrizes Curriculares Nacionais Gerais da Educação Básica. Brasília. 2013.

BRASIL. Ministério da Educação. Ensino Médio Inovador. 2009. Disponível em: <http://portal.mec.gov.br/dmdocuments/ensino_medioinovador.pdf>. Acesso em: 16 abr. 2017.

BRASIL. Ministério da educação. Guia de livros didáticos. PNLD 2015: matemática: ensino médio. Brasília, 2014. 108p.

BRASIL. Secretaria da Educação Básica. Formação de Professores do Ensino Médio: Ensino Médio e Formação Humana Integral. Pacto Nacional pelo Fortalecimento do Ensino Médio. 2013. Disponível em: <http://pactoensinomedio.mec.gov.br/images/pdf/cadernos/web_cad erno_1.pdf>. Acesso em 16 abr. 2017.

BRASIL. Secretaria de Educação Básica. Formação de professores do Ensino Médio. Etapa II Caderno V: Matemática. Pacto Nacional pelo Fortalecimento do Ensino Médio. Curitiba, 2014. Disponível em: <http://pactoensinomedio.mec.gov.br/images/pdf/cadernos/web_caderno_ 2_5.pdf>.Acesso em 20 abr. 2017.

BRASIL. Secretaria de Educação Média e Tecnológica. Parâmetros Curriculares Nacionais. Ensino Médio. Brasília, 2000.

BRASIL. Secretaria de Direitos Humanos da Presidência da República. Caderno em Educação em Direitos Humanos. Educação em Direitos Humanos: Diretrizes Nacionais - Brasília, 2013. Disponível em: <http://www.sdh.gov.br/assuntos/conferenciasdh/12a-conferencia-nacional- 
de-direitos-humanos/educacao-em-direitos-humanos/caderno-de-educacao-em-direitoshumanos-diretrizes-nacionais>. Acesso em 02 jun. 2017

BRASIL. Senado Federal. Lei de Diretrizes e Bases da Educação Nacional. Brasília. 2005. Disponível em: <https://www2.senado.leg.br/bdsf/bitstream/handle/id/70320/65.pdf?sequ ence=3>. Acesso em 16 abr. 2017.

CURY, C. R. J. A educação básica no Brasil. Educ. Soc. vol.23, n.80. Campinas, 2002.

COURANT, R.; ROBBINS, H. O que é matemática? Tradução: Adalberto da Silva Brito, Rio de Janeiro: Editora Ciência Moderna, 2000.

DRUCK, I. F. et al. Key mathematical concepts in the transition from secondary school to university. 12 ${ }^{\text {th }}$ International Congress on Mathematical Education, Seoul, Korea. 2012.

D'AMORE, B. Elementos de Didática de Matemática. Tradução Maria Cristina Bonomi. São Paulo: Livraria da Física, 2007.

EVES, H. Introdução à história da matemática. Tradução Hygino H. Domingues. 5a Edição. Campinas, Editora Unicamp, 2011.

FREIRE, Paulo. Pedagogia da autonomia. Saberes necessários à prática educativa. São Paulo: Editora Paz e Terra. 1996.

FREIRE, P.; FAUNDEZ, A. Por uma pedagogia da pergunta. 4. ed. Rio de Janeiro: Editora Paz e Terra, 1998. 158p.

GUZMÁN M. et al. Difficulties in the Passage from Secondary to Tertiary Education. Proceedings of the International Congress of Mathematicians. Berlin, Vol. III: Invited Lectures, pp. 747-762. 1998.

HEALY, Lulu; JAHN, A. P. Argumentação e prova na sala de aula de matemática: design colaborativo de cenários de aprendizagem. 31a Reunião Anual da ANPEd: 31a. Reunião Anual da ANPEd: Constituição Brasileira, Direitos Humanos e Educação. Recife, 2008. v. 1. p. $1-21$.

HEFEZ, Abramo. Aritmética. Rio de Janeiro: SBM,2014. Coleção PROFMAT; 08. 338 p.

JOSEPH, Miriam. O Trivium. As artes liberais da Lógica, da Gramática e da Retórica. Tradução Henrique Paul Dmyterko. São Paulo, Editora Realizações, 2002.

KUENZER, A. Educação \& Sociedade. Revista Quadrimestral de Ciência da Educação. №70, Ano XXI, abril. São Paulo,2000.

LIMA, Elon Lages. Curso de análise. v.1. 14.ed. Associação Instituto de Matemática Pura e Aplicada. Rio de Janeiro, Projeto Euclides, 2014. 432p. 
MASETTO, M. T. Inovação na aula universitária: espaço de pesquisa, construção de conhecimento interdisciplinar, espaço de aprendizagem e tecnologias de comunicação. Revista Perspectiva - UFSC. Florianópolis, v. 29, n. 2, 597-620. jul./dez. 2011 Disponível em: $\quad<$ https://periodicos.ufsc.br/index.php/perspectiva/article/download/2175795X.2011v29n2p597/22219>. Acesso em 06 jun. 2017

MOTTA, C. M. Ourobórus. O fracasso das disciplinas de Matemática Básica e Pré-Cálculo nas universidades brasileiras. Jornal dá Licença. Ano XIX. № 58, Universidade Federal Fluminense, Rio de Janeiro: mar. 2014. Disponível em: <http://www.dalicenca.uff.br/>. Acesso em: 04 fev. 2017.

MICHAELIS. Moderno Dicionário da Língua Portuguesa. Editora Melhoramentos, 2015 Disponível em: < http://michaelis.uol.com.br/moderno-portugues/>. Acesso em: 20 mai. 2017.

MIORIM, M. A. O Ensino de Matemática: Evolução e Modernização. 1995. 231 f. Tese (Doutorado em Educação) - Faculdade de Educação, Universidade de Campinas. Campinas, 1995.

NUNCA me sonharam. Direção: Cacau Rhoden. Produção: Marinha Farinha Filmes. 2017. Brasil. $84 \mathrm{~min}$.

O'CONNOR, J.J.; ROBERTSON, E.F. MacTutor History of Mathematics Archive. Disponível em <http://www-history.mcs.st-and.ac.uk/Chronology/30000BC_500BC.html>. Acesso em: 07 mai. 2017.

PIETROPAOLO, Ruy Cesar. (Re)Significar a Demonstração nos Currículos da Educação Básica e da Formação dos Professores de Matemática. Tese de Doutorado. PUC - São Paulo, Brasil. 2005.

PIRES, C. M. C. Currículos de matemática: da organização linear à ideia de rede. São Paulo: FTD, 2000.

PONTE, J. P. M. Investigar, ensinar e aprender. Actas do ProfMat (CD-ROM, pp. 25-39). Lisboa: APM, 2003.

PONTE, J. P. M. Gestão curricular em Matemática. In GTI (Ed.), O professor e o desenvolvimento curricular (pp. 11-34). Lisboa: APM, 2005.

PONTE, J. P. M. Explorar e Investigar em Matemática: Uma Actividade Fundamental no Ensino e na Aprendizagem. Unión Revista Iberoamericana De Educación Matemática Número 21. Pp.13-30. Março 2010.

ROQUE, Tatiana. História da Matemática. Uma Visão Crítica, Desfazendo Mitos e Lendas. Editora Zahar, 2012. 
SALATINO, A. T. Entre laços e redes de sociabilidade. Sobre jovens, celulares e escola contemporânea. 2014. 198 f. Dissertação (Mestrado em Educação) - Faculdade de Educação, Universidade de São Paulo. São Paulo, 2014.

ZABALA, A. A prática educativa. Como ensinar. Porto Alegre: Artmed, 1998. 224 p. 


\section{Apêndices}

APÊNDICE A - Atividade de Investigação - Funções afim crescentes e decrescentes

Nome:

Nome:

Nome:

Nome:
№:

№:

№:

№:

\section{Atividade de Investigação - Funções afim crescentes e decrescentes}

1ㅇ Ano $-2 \circ$ Trimestre -2017

Objetivo: Provar as seguintes proposições:

- Proposição 1: Se o coeficiente angular for positivo, então a função afim é crescente.

- Proposição 2: Se o coeficiente angular for negativo, então a função afim é decrescente.

\section{Parte I - Conjecturando}

Definição: A função $\begin{aligned} f: A & \rightarrow B \\ x & \rightarrow f(x)\end{aligned}$ é crescente em um conjunto $I \subset A$ se, para dois valores quaisquer $x_{1}, x_{2} \in I$, com $x_{2}>x_{1}$, tivermos $f\left(x_{2}\right)>f\left(x_{1}\right)$.

Em símbolos, $f$ é crescente quando $\left(\forall x_{1}, x_{2}\right)\left(x_{2}>x_{1} \Rightarrow f\left(x_{2}\right)>f\left(x_{1}\right)\right)$

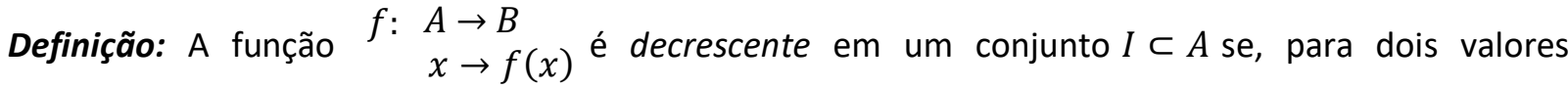
quaisquer $x_{1}, x_{2} \in I$, com $x_{2}>x_{1}$, tivermos $f\left(x_{2}\right)<f\left(x_{1}\right)$.

Em símbolos, $f$ é decrescente quando $\left(\forall x_{1}, x_{2}\right)\left(x_{2}>x_{1} \Rightarrow f\left(x_{2}\right)<f\left(x_{1}\right)\right)$

Agora responda: Analisando graficamente, quando uma função afim é crescente? Quando é decrescente? Justifique a sua resposta. 


\section{Parte II - Função afim Crescente}

Proposição: Se o coeficiente angular de uma função afim for positivo, então a função é crescente.

1. Considere a função afim $f(x)=2 x+1$. Escolhendo $x_{1}$ e $x_{2}$ adequados, verifique se $f$ é crescente.

\begin{tabular}{|l|l|l|l|l|l|}
\hline & $x_{2}$ & $x_{1}$ & $f\left(x_{2}\right)$ & $f\left(x_{1}\right)$ & \\
\hline Caso 1 & & & & & \\
\hline Caso 2 & & & & & \\
\hline Caso 3 & & & & & \\
\hline
\end{tabular}

2. Alterando os valores positivos do coeficiente angular $a$, é correto afirmar que a função é crescente para todo $a>0$ ? Você conseguiria justificar a sua resposta?

3. Calcule a diferença $x_{2}-x_{1}$ para os casos escolhidos no item 1 .

\begin{tabular}{|l|l|}
\hline & $x_{2}-x_{1}$ \\
\hline Caso 1 & \\
\hline Caso 2 & \\
\hline Caso 3 & \\
\hline
\end{tabular}


4. Vimos que, para analisarmos se uma função é crescente, a condição inicial é escolhermos $x_{1}$ e $x_{2}$ adequados de tal forma que $x_{2}>x_{1}$. Baseado neste fato, a diferença $x_{2}-x_{1}$ é um número real positivo, negativo ou zero? Justifique a sua resposta.

5. Vimos em sala de aula que $a=\frac{f\left(x_{2}\right)-f\left(x_{1}\right)}{x_{2}-x_{1}}$. Tomando como hipótese $a>0$, a diferença $f\left(x_{2}\right)-f\left(x_{1}\right)$ é um número real positivo, negativo ou zero? Justifique a sua resposta.

Dica: Relacione $a=\frac{f\left(x_{2}\right)-f\left(x_{1}\right)}{x_{2}-x_{1}}$ com a hipótese $a>0$

6. Prove que se $a>0$, então $\left(\forall x_{1}, x_{2}\right)\left(x_{2}>x_{1} \Rightarrow f\left(x_{2}\right)>f\left(x_{1}\right)\right)$ 


\section{Parte III - Função afim Decrescente}

Proposição: Se o coeficiente angular de uma função afim for negativo, então a função é decrescente.

7. Considere a função afim $f(x)=-2 x+1$. Escolhendo $x_{1}$ e $x_{2}$ adequados, verifique se $f$ é decrescente.

\begin{tabular}{|c|l|l|l|l|l|}
\hline & $x_{2}$ & $x_{1}$ & $f\left(x_{2}\right)$ & $f\left(x_{1}\right)$ & \\
\hline Caso 1 & & & & & \\
\hline Caso 2 & & & & & \\
\hline Caso 3 & & & & & \\
\hline
\end{tabular}

8. Alterando os valores negativos do coeficiente angular $a$, é correto afirmar que a função é decrescente para todo $a<0$ ? Você conseguiria justificar a sua resposta?

9. Calcule a diferença $x_{2}-x_{1}$ para os casos escolhidos no item 7 .

\begin{tabular}{|c|c|}
\hline & $x_{2}-x_{1}$ \\
\hline Caso 1 & \\
\hline Caso 2 & \\
\hline Caso 3 & \\
\hline
\end{tabular}


10. Vimos que, para analisarmos se uma função é crescente, a condição inicial é escolhermos $x_{1}$ e $x_{2}$ adequados de tal forma que $x_{2}>x_{1}$. Baseado neste fato, a diferença $x_{2}-x_{1}$ é um número real positivo, negativo ou zero? Justifique a sua resposta.

11. Vimos em sala de aula que $a=\frac{f\left(x_{2}\right)-f\left(x_{1}\right)}{x_{2}-x_{1}}$. Tomando como hipótese $a<0$, a diferença $f\left(x_{2}\right)-f\left(x_{1}\right)$ é um número real positivo, negativo ou zero? Justifique a sua resposta.

Dica: Relacione $a=\frac{f\left(x_{2}\right)-f\left(x_{1}\right)}{x_{2}-x_{1}}$ com a hipótese $a<0$

12. Prove que se $a<0$, então $\left(\forall x_{1}, x_{2}\right)\left(x_{2}>x_{1} \Rightarrow f\left(x_{2}\right)<f\left(x_{1}\right)\right)$ 